\title{
Synthesis, characterization, applications, and challenges of iron oxide nanoparticles
}

This article was published in the following Dove Press journal:

Nanotechnology, Science and Applications

19 August 2016

Number of times this article has been viewed

\author{
Attarad Ali \\ Hira Zafar' \\ Muhammad Zia' \\ Ihsan ul $\mathrm{Haq}^{2}$ \\ Abdul Rehman Phull ${ }^{3}$ \\ Joham Sarfraz Ali' \\ Altaf Hussain ${ }^{4}$ \\ 'Department of Biotechnology, \\ ${ }^{2}$ Department of Pharmacy, \\ Quaid-i-Azam University, Islamabad, \\ Pakistan; ${ }^{3}$ Department of Biology, \\ Kongju National University, Kongju, \\ South Korea; ${ }^{4}$ Department of \\ Materials Science and Engineering, \\ Institute of Space Technology, \\ Islamabad, Pakistan
}

\begin{abstract}
Recently, iron oxide nanoparticles (NPs) have attracted much consideration due to their unique properties, such as superparamagnetism, surface-to-volume ratio, greater surface area, and easy separation methodology. Various physical, chemical, and biological methods have been adopted to synthesize magnetic NPs with suitable surface chemistry. This review summarizes the methods for the preparation of iron oxide NPs, size and morphology control, and magnetic properties with recent bioengineering, commercial, and industrial applications. Iron oxides exhibit great potential in the fields of life sciences such as biomedicine, agriculture, and environment. Nontoxic conduct and biocompatible applications of magnetic NPs can be enriched further by special surface coating with organic or inorganic molecules, including surfactants, drugs, proteins, starches, enzymes, antibodies, nucleotides, nonionic detergents, and polyelectrolytes. Magnetic NPs can also be directed to an organ, tissue, or tumor using an external magnetic field for hyperthermic treatment of patients. Keeping in mind the current interest in iron NPs, this review is designed to report recent information from synthesis to characterization, and applications of iron NPs.
\end{abstract}

Keywords: superparamagnetism, iron oxide nanoparticles, surfactants, hyperthermia, biodistribution, bioelimination

\section{Introduction}

Nanoparticles (NPs) are at the forefront of rapid development in nanotechnology. Their exclusive size-dependent properties make these materials indispensable and superior in many areas of human activities. ${ }^{1}$ Being the most current transition metal in the Earth's crust, iron stands as the backbone of current infrastructure. ${ }^{2}$ However, in comparison to group elements such as cobalt, nickel, gold, and platinum, iron oxides are somewhat neglected. ${ }^{2}$ Iron and oxygen chemically combine to form iron oxides (compounds), and there are $\sim 16$ identified iron oxides. In nature, iron(III) oxide is found in the form of rust. ${ }^{3}$ Generally, iron oxides are prevalent, widely used as they are inexpensive, and play an imperative role in many biological and geological processes. They are also extensively used by humans, eg, as iron ores in thermite, catalysts, durable pigments (coatings, paints, and colored concretes), and hemoglobin. ${ }^{4}$ The three most common forms of iron oxides in nature are magnetite $\left(\mathrm{Fe}_{3} \mathrm{O}_{4}\right)$, maghemite $\left(\gamma-\mathrm{Fe}_{2} \mathrm{O}_{3}\right)$, and hematite $\left(\alpha-\mathrm{Fe}_{2} \mathrm{O}_{3}\right)$. These oxides are also very important in the field of scientific technology and are therefore the subject of this review. ${ }^{5}$ NPs composed of ferromagnetic materials and with size $<10-20 \mathrm{~nm}$ exhibit an inimitable form of magnetism, ie, superparamagnetism. The ferromag-
Correspondence: Attarad Ali Department of Biotechnology, Quaid-i-Azam University, Islamabad 45320, Pakistan Email attarad.ali@kiu.edu.pk 
netic materials include elemental metals, alloys, oxides, and other chemical compounds that are magnetized by an external magnetic field. This is an important phenomena normally present only in NP systems. ${ }^{2,6}$ Due to their low toxicity, superparamagnetic properties, such as surface area and volume ratio, and simple separation methodology, magnetic iron oxide $\left(\mathrm{Fe}_{3} \mathrm{O}_{4}\right.$ and $\gamma$ - $\left.\mathrm{Fe}_{2} \mathrm{O}_{3}\right)$ NPs have attracted much attention and are especially interesting in biomedical applications for protein immobilization, such as diagnostic magnetic resonance imaging (MRI), thermal therapy, and drug delivery. ${ }^{7}$ Iron's reactivity is important in macroscopic applications (particularly rusting), but is a dominant concern at the nanoscale. ${ }^{8}$ Finely divided iron is considered pyrophoric. These are the reasons that iron NPs could not capture much attention. The extreme reactivity of iron makes it difficult to study and inconvenient for applications. ${ }^{9}$ However, potent magnetic and catalytic properties have diverted the attention toward iron's potential. ${ }^{2}$ Iron oxide NPs can be easily and promptly induced into magnetic resonance by self-heating, applying the external magnetic field, and also by moving along the field of attraction. Synthetic methods, crystallization, size, shape, and quality of the iron oxide NPs greatly affect these behaviors. It is obvious that these approaches toward the synthesis of well-crystallized and size-controlled iron oxide NPs offer more prospects for these applications. ${ }^{10}$

The shapes of nanomaterials (NMs) also exert tremendous impact on their properties, including catalysis. ${ }^{11}$ Shape change shows crystal facets, and the atomic arrangements in each facet have reflective effects on its properties. The development of protocols for desired morphology, size, and shape is under consideration. ${ }^{12}$ Iron oxide NPs have been synthesized using mechanochemical (ie, laser ablation arc discharge, combustion, electrodeposition, and pyrolysis) and chemical (sol-gel synthesis, template-assisted synthesis, reverse micelle, hydrothermal, coprecipitation, etc) methods. ${ }^{13}$ Various shapes of iron oxides (ie, nanorod, porous spheres, nanohusk, nanocubes, distorted cubes, and self-oriented flowers) can be synthesized using nearly matching synthetic protocols, by simply changing the precursor iron salts. These novel protocols are easy to implement, economical, and control shape, in a sustainable manner. ${ }^{11}$ As well as the synthesis (to produce more compatibability in biosystems, proper functionalization, and molecular conjugation), surface modification of iron oxide is very important. In order to avoid chemical corrosion induced by instability, surface modification is the key post-synthesis step to produce iron NPs that are both biocompatible and stable. There are some other changes that may be applied as well and can result in additional physical and chemical properties onto iron oxide NPs. ${ }^{13}$

Currently, there is an increase in interest in ex vivo synthesis of NPs for diverse purposes, such as medical treatments, branches of industry production, and wide incorporation into diverse materials, such as cosmetics or clothing. ${ }^{14}$ NPs have a high surface-to-volume ratio that increases reactivity and possible biochemical activities. ${ }^{15}$ However, the interaction mechanism at the molecular level between NPs and biological systems is largely unknown. ${ }^{9}$ However, a thorough understanding of the role of nanosized engineered materials on plant physiology at the molecular level is still lacking. ${ }^{16}$ Plants, under certain conditions, are capable of producing natural mineralized NMs necessary for their growth. ${ }^{17}$ Nano$\mathrm{TiO}_{2}$ treatment, at proper concentration, accelerates the germination of aged seeds of spinach and wheat in comparison to bulk $\mathrm{TiO}_{2 \text {. }}{ }^{18,19}$ Similarly, carbon nanotubes improve seed germination and root growth by penetrating thick seed coats and supporting water uptake. The effect of NPs on plants varies from plant to plant and species to species. ${ }^{16}$ In view of the acclaimed reports on the use of nanotechnology as an emerging discipline in almost all fields of technology, it is important to understand the course of germination in relation to NPs. Recent advances in nanotechnology and its use in the field of agriculture are increasing astonishingly; therefore, it is tempting to understand the role of NPs in the germination and growth of seeds. ${ }^{14}$ Dispersing of iron NPs upon mercury is considered one of the earliest convenient methods for producing well-defined iron NPs. Some methods have also been successfully used for organic-solvent-based procedures. ${ }^{20}$ However, later mercury-based methods were replaced with organic-solvent-based methods. This change has been due to the toxic nature of mercury vapors, the low solubility of iron in mercury, and the comparative ease of removing organic solvents. ${ }^{2}$ In the current era, ultrafine magnetic iron oxide particles are obtained using complex structures or organized assemblies. ${ }^{21}$ Various saturated and unsaturated fatty acids as primary and secondary surfactants, are also used to prepare stable aqueous magnetic suspensions. ${ }^{9}$

\section{Methods for the preparation of iron NPs}

Iron oxide magnetic NPs with appropriate surface chemistry are prepared by various methods (Figure 1), such as wet chemical, dry processes, or microbiological techniques. ${ }^{2,7} \mathrm{~A}$ detailed comparison of synthesis methods is given in Table 1, aiming to help researchers who are occupied in this field to 


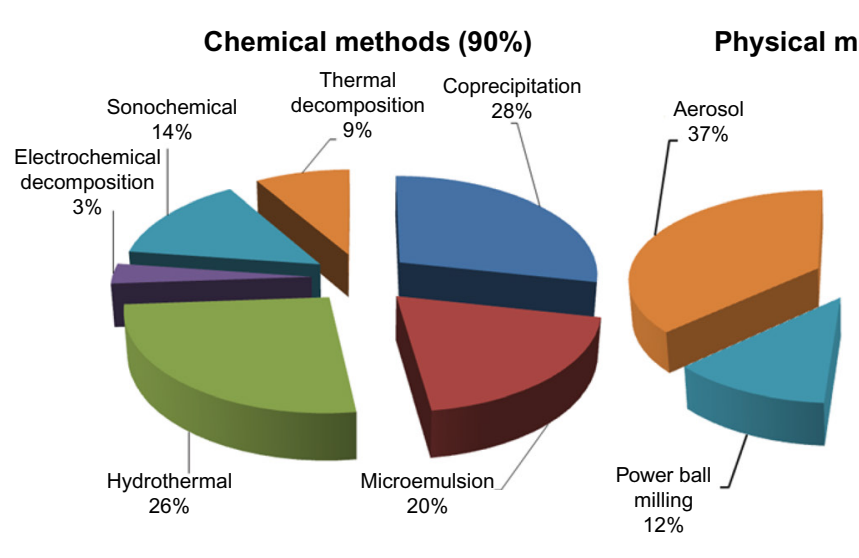

Physical methods (8\%)

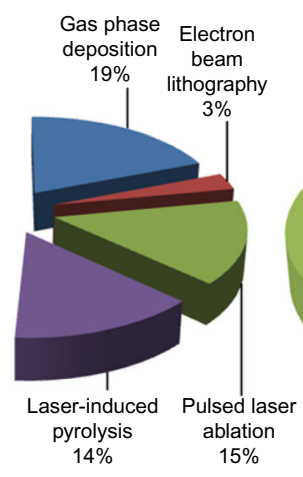

\section{Biological methods (2\%)}

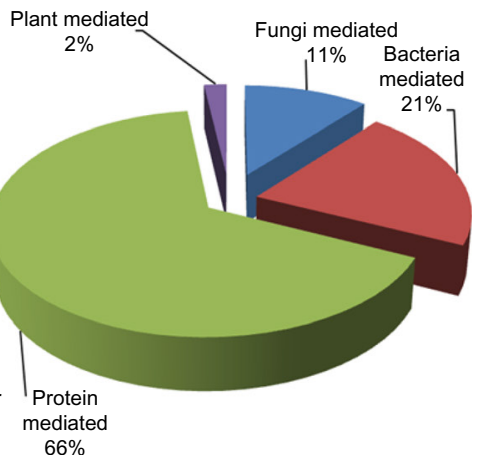

Figure I A comparison of the synthesis of SPIONs by three different routes.

Abbreviations: NPs, nanoparticles; SPIONs, superparamagnetic iron oxide NPs.

Table I Iron NP synthesis techniques and their comparison with respect to their product morphology, advantages, and disadvantages

\begin{tabular}{|c|c|c|c|c|c|c|}
\hline \multirow{2}{*}{$\begin{array}{l}\mathbf{S} \# \\
I\end{array}$} & \multicolumn{2}{|c|}{ Techniques } & \multirow{2}{*}{$\begin{array}{l}\text { Product morphology } \\
\text { Spheres and irregular } \\
\text { spheres }\end{array}$} & \multirow{2}{*}{$\begin{array}{l}\text { Advantages } \\
\text { Easy to execute }\end{array}$} & \multirow{2}{*}{$\begin{array}{l}\text { Disadvantages } \\
\text { Problematic in controlling } \\
\text { the size of particle }\end{array}$} & \multirow{2}{*}{$\begin{array}{l}\text { References } \\
22\end{array}$} \\
\hline & Physical & Deposition of gas phase & & & & \\
\hline & & Electron beam lithography & Spheres and rods & $\begin{array}{l}\text { Well-controlled } \\
\text { interparticle spacing }\end{array}$ & $\begin{array}{l}\text { Requires expensive and } \\
\text { highly complex machines }\end{array}$ & 30 \\
\hline \multirow[t]{10}{*}{2} & Chemical & Sol-gel method & $\begin{array}{l}\text { Spheres, irregular spheres, } \\
\text { porous and nonporous } \\
\text { spheres, or spindles }\end{array}$ & $\begin{array}{l}\text { Aspect ratio, precisely } \\
\text { controlled in size, and } \\
\text { internal structure }\end{array}$ & $\begin{array}{l}\text { High permeability, weak } \\
\text { bonding, low wear } \\
\text { resistance }\end{array}$ & 4 \\
\hline & & Oxidation & $\begin{array}{l}\text { Irregular elongated and } \\
\text { small spheres }\end{array}$ & $\begin{array}{l}\text { Narrow size distribution } \\
\text { and uniform size }\end{array}$ & Ferrite colloids of small size & 31,32 \\
\hline & & Chemical coprecipitation & Spheres & Simple and effective & $\begin{array}{l}\text { Inappropriate for the } \\
\text { synthesis of high untainted, } \\
\text { precise stoichiometric } \\
\text { phase }\end{array}$ & 24,28 \\
\hline & & Hydrothermal & $\begin{array}{l}\text { Elongated, compact } \\
\text { irregular spheres, and } \\
\text { numerous shapes }\end{array}$ & $\begin{array}{l}\text { Particle size and shapes are } \\
\text { easily controllable }\end{array}$ & $\begin{array}{l}\text { High pressure and reaction } \\
\text { temperature }\end{array}$ & 23 \\
\hline & & Flow injection & $\begin{array}{l}\text { Small rods, irregular } \\
\text { spheres, sheets, or rhombic } \\
\text { shapes }\end{array}$ & $\begin{array}{l}\text { Homogeneity with high } \\
\text { mixing with a accurate } \\
\text { control of the procedure } \\
\text { and good reproducibility }\end{array}$ & $\begin{array}{l}\text { Under a laminar flow } \\
\text { regime in a capillary } \\
\text { reactor, it requires } \\
\text { continuous or segmented } \\
\text { mixing of reagents }\end{array}$ & 33 \\
\hline & & Electrochemical & $\begin{array}{l}\text { Spherical NPs, nanorods, } \\
\text { hexagonal nanocrystals, and } \\
\text { facets }\end{array}$ & Controllable particle size & Inability to reproduce & 4 \\
\hline & & Aerosol/vapor phase & $\begin{array}{l}\text { Mesoporous single crystals } \\
\text { and small particles, } \\
\text { octahedral cages }\end{array}$ & Large-scale products & $\begin{array}{l}\text { Requires very high } \\
\text { temperatures }\end{array}$ & 34 \\
\hline & & $\begin{array}{l}\text { Sonochemical } \\
\text { decomposition }\end{array}$ & $\begin{array}{l}\text { Bipyramids, spheres, or } \\
\text { truncated rods }\end{array}$ & $\begin{array}{l}\text { Size distribution in narrow } \\
\text { particle }\end{array}$ & $\begin{array}{l}\text { Still, mechanism is not well } \\
\text { understood }\end{array}$ & 35 \\
\hline & & Supercritical fluid method & $\begin{array}{l}\text { Mesoporous single crystals, } \\
\text { elongated irregular } \\
\text { nanotubes }\end{array}$ & $\begin{array}{l}\text { No organic solvents } \\
\text { involved and efficient } \\
\text { control of the particle size }\end{array}$ & $\begin{array}{l}\text { Requires high temperatures } \\
\text { and critical pressure }\end{array}$ & 5 \\
\hline & & Using nanoreactors & $\begin{array}{l}\text { Spheres, hollow and } \\
\text { spherical NPs }\end{array}$ & $\begin{array}{l}\text { Likelihood to specifically } \\
\text { control the size of NPs }\end{array}$ & Complicated conditions & 36 \\
\hline 3 & Biological & Microbial incubation & $\begin{array}{l}\text { Small platelets, spherical or } \\
\text { rod-like spheres, irregular } \\
\text { spheres }\end{array}$ & $\begin{array}{l}\text { Good reproducibility and } \\
\text { scalability, high yield, and } \\
\text { low cost }\end{array}$ & Slow and laborious & 25 \\
\hline
\end{tabular}

Abbreviations: NPs, nanoparticles; S \#, serial number. 
choose appropriate suitable synthesis methods. Briefly, iron NPs can be synthesized by the following three methods:

1. Physical methods: these are elaborate procedures which suffer from the inability to control the size of particles ${ }^{22}$ in the nanometer range.

2. Chemical preparation methods: these methods are simple, tractable, and efficient, in which the size, composition, and even the shape of the NPs can be managed. ${ }^{23}$ Iron oxides can be synthesized through the coprecipitation of $\mathrm{Fe}^{2+}$ and $\mathrm{Fe}^{3+}$ by the addition of a base. ${ }^{24}$ The size, shape, and composition of iron NPs synthesized through chemical methods depend on the type of salt used, $\mathrm{Fe}^{2+}$ and $\mathrm{Fe}^{3+}$ ratio, $\mathrm{pH}$, and ionic strength. ${ }^{4}$

3. Biological methods. ${ }^{25}$

Among these methodologies, chemical-based synthesis methods are mostly adopted due to low production cost and high yield. In general, magnetites are synthesized by adding a base to an aqueous mixture of $\mathrm{Fe}^{2+}$ and $\mathrm{Fe}^{3+}$ chloride at 1:2 molar ratio, resulting in black color. ${ }^{10}$ The chemical reaction of $\mathrm{Fe}_{3} \mathrm{O}_{4}$ precipitation is given in Equations 1 and 2. The overall reaction is written as follows: ${ }^{26}$

$$
\mathrm{Fe}^{2+}+2 \mathrm{Fe}^{3+}+8 \mathrm{OH} \rightarrow \mathrm{Fe}_{3} \mathrm{O}_{4}+4 \mathrm{H}_{2} \mathrm{O}
$$

Under oxygen-free environment, a complete precipitation of $\mathrm{Fe}_{3} \mathrm{O}_{4}$ is likely between $\mathrm{pH} 9$ and 14 , maintaining a molar ratio of $\mathrm{Fe}^{3+}: \mathrm{Fe}^{2+}(2: 1) . \mathrm{Fe}_{3} \mathrm{O}_{4}$ might also be oxidized as:

$$
\mathrm{Fe}_{3} \mathrm{O}_{4}+0: 25 \mathrm{O}_{2}+4: 5 \mathrm{H}_{2} \mathrm{O} \rightarrow 3 \mathrm{Fe}(\mathrm{OH})^{3+}
$$

The physical and chemical properties of NPs may vary depending upon the conditions. To prevent iron NPs from oxidation and agglomeration, $\mathrm{Fe}_{3} \mathrm{O}_{4} \mathrm{NPs}^{4}$ are usually coated with organic or inorganic molecules. However, it is a prerequisite to synthesize magnetic NPs in oxygen-free environment, most preferably in the presence of $\mathrm{N}_{2}$ gas. Bubbling nitrogen gas not only protects NP oxidation but also reduces the size. ${ }^{26,27}$

Each method described earlier has its own advantages and disadvantages (Table 1). Although physical methods are easy to perform, controlling the particle size is difficult. While in wet chemical preparation, particle size can be somewhat controlled by adjusting the conditions. The chemical methods include electrochemical method, sol-gel method, supercritical fluid method, hydrothermal method, chemical coprecipitation, sonochemical decomposition method, flow injection method, and nanoreactors. However, in all these techniques, aqueous medium is a most efficient pathway to obtain iron magnetic NPs. It has been demonstrated the particle size as well as the polydispersity of the NPs could be tailored by changing the associated factors such as $\mathrm{Fe}^{2+/} \mathrm{Fe}^{3+}$ ratio, ${ }^{24,28}$ base $(\mathrm{NaOH}$, ammonium hydroxide, and $\left.\mathrm{CH}_{3} \mathrm{NH}_{2}\right)$, and ionic strength $\left(\mathrm{N}\left(\mathrm{CH}_{3}\right)^{4+}\right.$, $\mathrm{CH}_{3} \mathrm{NH}^{3+}, \mathrm{NH}^{4+}, \mathrm{Na}^{+}, \mathrm{Li}^{+}$, and $\left.\mathrm{K}^{+}\right) .{ }^{4}$ Some other factors also influence on the size of the NPs, ${ }^{29} \mathrm{eg}$, an increase in mixing rate, temperature, inlet of nitrogen gas, agitation, $\mathrm{pH}$, and reactants ratio. On the other hand, microbial methods ensure low cost, reproducibility, high yield, and scalability, but are time-consuming. ${ }^{25}$

\section{Brief techniques for the synthesis of magnetic NPs}

Several synthesis routes to achieve shape, size, crystallinity, dispersity, and magnetic behavior have been developed. ${ }^{7}$ Some of them are discussed in Figure 1. The three most important published routes or procedures for the synthesis of iron oxide magnetic NPs are represented in Figure 1.

\section{Liquid phase methods}

These methods are simple and allow the preparation of magnetic NPs with rigorous control of size and shape. Homogeneous precipitation reactions are used to synthesize uniform sizes that involve the separation of the nucleation and growth of the nuclei. ${ }^{24}$ One of the classic models for synthesis is proposed by LaMer and Dinegar ${ }^{37}$ in which the nuclei are allowed to slowly diffuse, resulting in growth, until the final size is attained. In order to attain monodisparity, nucleation should be avoided during the period of growth., ${ }^{7,37}$

Coprecipitation from aqueous solutions is one of the most frequently used methods. The reaction of Fe(II) salt, in aqueous solution, to a base in the presence of mild oxidant synthesizes spherical NP of 30-100 nm. ${ }^{24,28}$ The factors on which the phase and size of the particles depend are the concentration of cations, the presence of counter ions, and $\mathrm{pH}$ of the solution. Change in $\mathrm{pH}$ and ionic strength play a vital role in controlling the mean size of the particles (from $15 \mathrm{~nm}$ to $2 \mathrm{~nm}$ ). ${ }^{38} \mathrm{NPs}$ usually aggregate because of large surface-area-to-volume ratio and to reduce surface energy. ${ }^{39}$ The anionic surfactants as dispersing agents are added to stabilize them. ${ }^{40}$ The stabilization can also be achieved by coating the surface with proteins, ${ }^{41}$ starches, nonionic detergents, or polyelectrolytes ${ }^{7}$ as the adsorption of such substances stabilizes the electrolyte concentrations of particles that would otherwise be high enough. ${ }^{6,42}$ The first controlled preparation using alkaline precipitation of $\mathrm{FeCl}_{3}$ and $\mathrm{FeCl}_{2}$ of superparamagnetic iron oxide particles was performed by Massart. ${ }^{43}$ Originally, synthesized 
magnetite $\left(\mathrm{Fe}_{3} \mathrm{O}_{4}\right)$ particles were roughly spherical, and their diameter measured by X-ray diffraction analysis was $8 \mathrm{~nm} .{ }^{44}$ The parameters of this methodology demonstrate the influence of base (ammonia, $\mathrm{CH}_{3} \mathrm{NH}_{2}$, and $\mathrm{NaOH}$ ), $\mathrm{pH}$, added cations $\left(\mathrm{N}\left(\mathrm{CH}_{3}\right)^{4+}, \mathrm{K}^{+}, \mathrm{CH}_{3} \mathrm{NH}_{3}^{+}, \mathrm{Li}^{+}, \mathrm{Na}^{+}\right.$, and $\left.\mathrm{NH}_{4}^{+}\right)$, and $\mathrm{Fe}_{3}^{+} / \mathrm{Fe}_{2}^{+}$ ratio on the yield of this reaction and the diameter and polydispersity of the synthesized NPs. After the modulation of the studied parameters, it is possible to obtain particles with a size ranging from $16.6 \mathrm{~nm}$ to $4.2 \mathrm{~nm} .^{7,28}$

\section{Two-phase methods (microemulsion)}

Water-in-oil microemulsion consists of nanosized water droplets dispersed in oil phase which are stabilized by surfactant molecules. ${ }^{45}$ The nanocavities lemmatize particle growth, nucleation, and agglomeration. ${ }^{46}$ The diversity of NPs due to surfactant, nature, physiological conditions, etc, is the main advantage of this technology. ${ }^{47}$ For the synthesis of magnetite NPs, nanoemulsion containing iron source and sodium hydroxide are mixed together, later lysed with acetone to remove the surfactant and washed with ethanol. Normally, the colloidal NPs exhibit superparamagnetic behavior with high magnetization values. ${ }^{6,7,31}$

There are several dissolved components in water and oil phase; therefore, the selection of the surfactant (and cosurfactant) depends upon the physicochemical characteristics of the system. Different surfactants, such as cationic, anionic, or nonionic, can be used. The main disadvantage associated with this method is adverse effects of residual surfactants on the properties and difficulty in scale-up procedures. ${ }^{48,49}$

\section{Sol-gel method}

This method revolves around hydroxylation and condensation of molecular precursors in solution. Obtained "sol" from nanometric particles is then dried or "gelled" either by solvent removal or by chemical reaction to obtain threedimensional metal oxide network. The solvent used is water, but the precursors can be hydrolyzed using an acid or a base. Basic catalysis yields a colloidal gel, whereas acid catalysis formulates a polymeric gel. ${ }^{50}$ The reaction is performed at room temperature; however, heat treatment is required to obtain the final crystalline state. ${ }^{51}$ Equation 3 shows the reaction mechanism of magnetite particle formation from an aqueous iron(III) solution by sol-gel system.

$$
\begin{aligned}
& \text { Disproportionation: } \mathrm{Fe}^{3+}+\mathrm{H}_{2} \mathrm{O} \mathrm{Fe}(\mathrm{OH})_{x}^{3-x} \\
& \text { Oxidation: } \mathrm{Fe}(\mathrm{OH})_{x}^{3-x} \\
& \text { Magnetite dehydration: } \mathrm{Fe}_{3} \mathrm{O}_{4}\left(\mathrm{pH} 9.0,60^{\circ} \mathrm{C}\right)
\end{aligned}
$$

Nanotechnology, Science and Applications 2016:9
The parameters influencing synthesis are $\mathrm{pH}$, nature, and concentration of salt precursor, kinetics, temperature, agitation, and properties of gel. ${ }^{52}$ Magnetic ordering in this procedure depends on the volume and phase of solvent but is sensitive to dispersion and size distribution. ${ }^{45}$ The associated advantages include synthesis of materials with a predetermined structure, pure amorphous phase, monodispersity, good control of particle size, control of microstructure, homogeneity of the products, and chances to generate embed molecules, which maintain their stability and properties within the matrix. ${ }^{7}$ It is an easy method for the production of metal oxides from salts at specific conditions.

Iron oxide-silica aerogel composites are also prepared using this method ${ }^{53}$ and are found more reactive than conventional iron oxide. Commercial precursors (tetraethyl orthosilicate and Fe(III) solutions) are dissolved in an alcoholic aqueous medium, and the gels formed are heated to generate the final materials. ${ }^{45}$ The increased reactivity is recognized by large surface area of iron oxide NPs. ${ }^{8}$

\section{Gas/aerosol phase methods}

For continuous, high, and direct production of defined magnetic NPs, spray and laser pyrolysis is an efficient technique. ${ }^{54} \mathrm{~A}$ solution of ferric salts is sprayed into the reactor in the presence of reducing agent. The solute condenses while the solvent evaporates. ${ }^{55}$ Later, the dried residue consisting of particles is obtained, whose size is same as the original. Maghemite particles from $5 \mathrm{~nm}$ to $60 \mathrm{~nm}$ with diverse shapes have been generated using different iron precursors. $^{45}$

Laser pyrolysis of organometallic precursors ${ }^{56}$ depends on the resonant interaction, reactant, and/or sensitizer; however, one should be in gaseous phase. A sensitizer is excited by the combination of $\mathrm{CO}_{2}$ laser radiation that transfers energy absorbed to the reactants. ${ }^{57}$ The energy is provided by heating the mixture of gases with $\mathrm{CO}_{2}$ laser. The chemical reaction continues until the threshold level of nuclei is attained, finally the nucleation of particles occurs. ${ }^{49}$ The nucleated particles produced during the reaction are entrained by the gas stream and are gathered at the exit. ${ }^{58}$ Hasany et $\mathrm{al}^{54}$ studied the production of iron oxide by using gas phase, laminar diffusion flame methodology for the synthesis of reduced iron oxide NPs. Gas/aerosol method usually produces high-quality products, although the yield is low. Pure product can be further obtained by decreasing gas impurities and controlling the time of heating and gas concentrations. The drawback of these methodologies is the expense associated with them. ${ }^{7}$ 


\section{Polyols method}

Polyols method is a significant technique for the preparation of well-defined NPs with controlled shape and size..$^{59}$ After controlling the kinetics of the precipitation, non-agglomerated metal particles with well-defined shape and size can be obtained. The average size of the metal particles is controlled by reactive medium, heterogeneous nucleation. The synthesis steps are independent of resulting uniform particle size. Iron NPs of $100 \mathrm{~nm}$ can be obtained by ferrous hydroxide in organic media. ${ }^{60}$ The solvents used, such as polyols and polyethylene glycol, offer interesting properties due to their high dielectric constants. These solvents can dissolve inorganic compounds, and due to their relatively high boiling points they offer a wide operating temperature range (from $25^{\circ} \mathrm{C}$ to the boiling point). ${ }^{61}$ Polyols function as both reducing and stabilizing agents to control particle growth. These also prevent the aggregation of NPs ${ }^{61}$ Type of polyols, salt ratio, concentration, and other physiological conditions affect growth, shape, size, and yield of the particles. The yield and size of Fe particles are found to be dependent upon the reduction potential of the polyols.

\section{Hydrothermal reaction methods}

The hydrothermal reactions are performed in a reactor or autoclave in an aqueous media, where the pressure of $>2,000 \mathrm{psi}$ and temperature of $>200^{\circ} \mathrm{C}$ are maintained. The dehydration of metal salts and low solubility of oxides in aqueous phase supersaturate the medium. ${ }^{62} \mathrm{~A}$ thorough investigation has been performed by Hao and Teja ${ }^{62}$ to study the effects of temperature, precursor, and the time on morphology and particle size. The precursor concentration increases the particle size, while residence time has more effect than concentration. Monodispersed particles usually produce at short residence times. ${ }^{63}$ The effect of changing the precursor (eg, ferric nitrate) concentration (with all other variables kept constant) is studied in various experiments, and the transmission electron microscopy (TEM) images of particles obtained were found to be spherical with an average particle radius of $15.6 \pm 4.0 \mathrm{~nm}$. A few larger rhombic particles with an average particle size of $27.4 \pm 7.0 \mathrm{~nm}$ were also observed in some experiments (changing precursor concentration). However, the particles were mostly rhombic, and there were few smaller spherical particles. ${ }^{7}$

\section{Sonolysis}

Iron oxide can be synthesized by the decomposition/sonolysis of organometallic precursors. Polymers, organic capping agents, or structural hosts are used to limit the growth of the NPs. ${ }^{64}$ Figure 2 represents the general steps of the synthesis

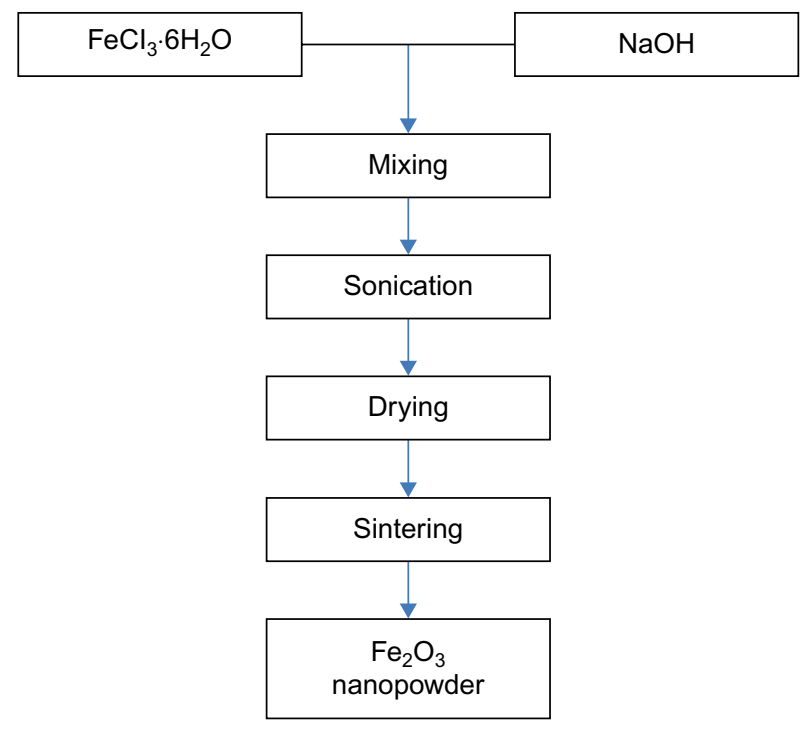

Figure 2 Flowchart of sonochemical synthesis of iron oxide. Note: Data from a previous study. ${ }^{65}$

of iron oxide using sonolysis technique. Ultrasonic irradiation mainly causes cavitation in an aqueous medium, where the formation, growth, and collapse of microbubbles occur. ${ }^{65}$ Cavitation can create a temperature of around $5,000^{\circ} \mathrm{C}$ and a pressure of $>1,800 \mathrm{KPa}$, which facilitates many unusual chemical reactions ${ }^{66}{ }^{6}$ Thermal induction mainly offers crystalline NPs, while ultrasonic induction yields amorphous NPs. ${ }^{67}$ Pinkas et al ${ }^{67}$ studied the sonochemical synthesis of $3 \mathrm{~nm}$-sized yttrium iron oxide NPs. Globular agglomerates, analyzed by scanning electron microscopy (SEM) and TEM, confirmed that they were embedded in an acetate matrix. However, stoichiometry can be achieved by Y and Fe molar ratio as starting materials. ${ }^{7}$

\section{Microwave irradiation}

Microwave chemistry has gained much attention in recent years, as it has been used in preparative chemistry and material synthesis since $1986 .{ }^{68}$ The shorter crystallization time and homogeneous nucleation due to uniform heat of microwave oven are major disadvantages of this system. Kijima et $\mathrm{l}^{68}$ reported that the synthesis of ultrafine $\alpha-\mathrm{Fe}_{2} \mathrm{O}_{3} \mathrm{NPs}$ with an extremely narrow distribution by microwave heating resulted in significantly high electrochemical performance due to uniformity and size.$^{69}$ Most primary particles had ellipsoid shapes and were connected to each other. The average diameter of these primary particles was $<10 \mathrm{~nm}$ with single crystals confined by electron diffraction pattern. Parsons et $\mathrm{l}^{69}$ also reported the synthesis of iron oxide/oxyhydroxide NPs by microwave ovens. The controlled growth and structure of NPs are usually due to slow reaction of the reactants (iron salt and sodium hydroxide). 


\section{Chemical properties of iron NPs}

Iron NPs are extremely reactive with oxidizing agents, particularly with air. $^{2}$ For the complete and permanent protection from oxidizing, each NP is covered with a thin covering that has little or no impact on the magnetic property of NPs, different coating materials are used for this purpose, ie, gold and silica, but these coatings weaken the magnetic properties. ${ }^{23}$ Magnesium coating is also used, which has little effect on magnetic properties of iron particles. However, the produced material is not simple; iron nanoparticles are submerged within submicrometer magnesium particles. ${ }^{70}$ The most convenient method for the production of almost fully magnetic iron particles protected from oxidation is the coating of iron carbide; however, the resulting particles are greater in size $(20-100 \mathrm{~nm})$, polydisperse, and ferromagnetic, so are not ideal. Even so, this represents real progress. ${ }^{71}$ Air-stable cobalt NPs are synthesized by the decomposition of cobalt carbonyl in the presence of aluminum alkyls. Iron carbonyl synthesized in same manner produced meaningful results. ${ }^{2}$ Iron oxide NMs have great importance because of their magnetic properties and wide applications. The correlation among numerous characteristic features of magnetic NPs prepared through different approaches is shown in Table 2.

The investigation of iron and iron oxide NPs in biological and material sciences is booming in recent times because of their various chemical and physical properties. They exhibit multiple potential applications, including magnetic fluid, magnetic micro-device, MRI, magnetic hyperthermia, water purification, and drug delivery. ${ }^{27,72-74}$ Significant sizedependent structural and optical properties of colloidal iron and iron oxide NPs correspond to electrical structure and quantum size effects of NPs. The respective synthesis method can affect their size and crystal structure as well. ${ }^{75}$

Iron NPs display dual characteristics of zerovalent iron (reduction) and iron hydroxides (complex formation). A number of studies in the field of magnetic NPs have been carried out on various types of iron and iron oxides (typically $\mathrm{Fe}_{3} \mathrm{O}_{4}$ magnetite, $\mathrm{Fe}^{+2} \mathrm{Fe}^{+3}{ }_{2} \mathrm{O}_{4}$, ferrimagnetic, superparamagnetic $<15 \mathrm{~nm}$ ): a- $\mathrm{Fe}_{2} \mathrm{O}_{3}$ (hematite, weakly ferromagnetic, or antiferromagnetic), $\mathrm{c}-\mathrm{Fe}_{2} \mathrm{O}_{3}$ (maghemite, ferrimagnetic), $\mathrm{FeO}$ (antiferromagnetic), $\mathrm{e}-\mathrm{Fe}_{2} \mathrm{O}_{3}$, and $\mathrm{b}-\mathrm{Fe}_{2} \mathrm{O}_{3}{ }^{6,42}$ Among those, magnetite and maghemite are well known and promising candidates since their biocompatibility has been proven. ${ }^{23}$ During the synthesis, the simultaneity of $\mathrm{Fe}_{3} \mathrm{O}_{4}$ and $\gamma-\mathrm{Fe}_{2} \mathrm{O}_{3}$ can be attributed to the oxidation of magnetite to maghemite. Both NPs are single crystalline in structure, and each is made of a magnetic domain. Consequently, they show the superparamagnetic behavior and only retain magnetic moment in the presence of an external magnetic field. On detaching magnetic field, these NPs will immediately return to their nonmagnetic states. ${ }^{76}$ After the synthesis, iron NPs rapidly form layers of iron oxide at their surface. These layers do not necessarily penetrate the whole particle; therefore, the NP itself may disparately be a core-shell structure to a pure iron NP. ${ }^{77}$ Under ambient conditions, $\mathrm{Fe}_{3} \mathrm{O}_{4}$ NPs are not very stable and can easily be oxidized to $\mathrm{Fe}_{2} \mathrm{O}_{3}$ or dissolve in an acidic medium. Therefore, to avoid possible oxidation in the air, preparation must be performed in an anaerobic condition. Based on oxidation, $\mathrm{Fe}_{3} \mathrm{O}_{4} \mathrm{NPs}$ can be used to synthesize $\mathrm{Fe}_{2} \mathrm{O}_{3} \mathrm{NPs}$ (under oxygen atmosphere or annealing treatment). Because of the chemical stability in acidic

Table 2 Fabrication of iron oxide NPs: comparison of different methods

\begin{tabular}{|c|c|c|c|c|c|}
\hline \multirow{2}{*}{$\begin{array}{l}\text { Characteristics of } \\
\text { the iron oxide }\end{array}$} & \multicolumn{5}{|c|}{ Synthesis methods of iron oxide NPs } \\
\hline & $\begin{array}{l}\text { Aerosol/vapor } \\
\text { (pyrolysis) method }\end{array}$ & $\begin{array}{l}\text { Gas deposition } \\
\text { method }\end{array}$ & $\begin{array}{l}\text { Bulk solution } \\
\text { method }\end{array}$ & Sol-gel method & $\begin{array}{l}\text { Microemulsion } \\
\text { method }\end{array}$ \\
\hline $\begin{array}{l}\text { Size and size } \\
\text { distribution }\end{array}$ & $\begin{array}{l}\text { Approximately 5-60 nm } \\
\text { with broad distribution }\end{array}$ & $\begin{array}{l}\text { Approximately } \\
5-50 \mathrm{~nm} \text { with narrow } \\
\text { size distribution }\end{array}$ & $10-50 \mathrm{~nm}$ & $20-200 \mathrm{~nm}$ & $4-15 \mathrm{~nm}$ \\
\hline Morphology & Spherical & Spherical & Spherical & Spherical & Cubic or spherical \\
\hline Magnetization values & $\begin{array}{l}10-50 \text { emu/g with } \\
\text { desired magnetic } \\
\text { property }\end{array}$ & $>20 \mathrm{emu} / \mathrm{g}$ & $\begin{array}{l}20-50 \text { emu/g with } \\
\text { superparamagnetic } \\
\text { behavior }\end{array}$ & $\begin{array}{l}\text { I0-40 emu/g with } \\
\text { paramagnetic } \\
\text { behavior }\end{array}$ & $\begin{array}{l}>30 \text { emu/g with } \\
\text { superparamagnetic } \\
\text { behavior }\end{array}$ \\
\hline Advantages & High production rate & $\begin{array}{l}\text { Useful for protective } \\
\text { coatings and thin film } \\
\text { deposition }\end{array}$ & Synthesis in bulk & $\begin{array}{l}\text { Desired shape and } \\
\text { length and hybrid } \\
\text { NPs }\end{array}$ & Uniform properties \\
\hline Disadvantages & $\begin{array}{l}\text { Large aggregates are } \\
\text { formed }\end{array}$ & $\begin{array}{l}\text { Requires very high } \\
\text { temperatures }\end{array}$ & $\begin{array}{l}\text { Uncontrolled oxidation } \\
\text { of magnetite to } \\
\text { maghemite, diamagnetic } \\
\text { contribution }\end{array}$ & $\begin{array}{l}\text { Product contains } \\
\text { sol-gel matrix } \\
\text { components }\end{array}$ & $\begin{array}{l}\text { Surfactants are difficult to } \\
\text { remove; small amount can } \\
\text { be synthesized }\end{array}$ \\
\hline
\end{tabular}

Abbreviation: NPs, nanoparticles. 
or alkaline environment, oxidation does not influence $\mathrm{Fe}_{2} \mathrm{O}_{3}$ NPs. Chemically, the bare iron or iron oxide NPs are very active and can easily be oxidized in air (especially magnetite), generally resulting in the loss of dispersibility and magnetism. Thus, it is important to keep the stability of magnetic iron oxide NPs by developing some effective protection strategies and providing proper surface coating (or grafting) with organic molecules, polymers, surfactants, biomolecules, or inorganic layer such as silica, metal, metal sulfide, metal oxide, or nonmetal elementary substances. ${ }^{23}$

\section{Surface coatings of NPs}

Iron oxides with bare surface tend to agglomerate due to strong magnetic attraction among particles, van der Waals forces, and high energy surface. ${ }^{78}$ Consequently, the reticuloendothelial system eliminates the agglomerated iron oxide NPs. ${ }^{79}$ High concentration of local Fe ions is also toxic to organisms from Fe dissolution. ${ }^{80}$ These can be avoided by coating a shell on the iron oxide NP surface which makes them hydrophilic, compatible to bioenvironments, and functionalized. ${ }^{13}$ The appropriate surface coating allows a targetable delivery with particle localization in a specific area and is also considered nontoxic and biocompatible. So far, most work has been carried out to improve the biocompatibility of this material, but regarding the improvement in the quality of magnetic particles, their size distribution, shape, and surface, very few scientific investigations and developments have been carried out. The nature of surface coating of NPs and geometric arrangement not only determines the overall size of the colloid but also plays a significant role in biokinetics and biodistribution of NPs in the body. ${ }^{31,81}$ For NPs the types of coating or derivatization depends on the application, and is aimed at either inflammation response or anticancer agents. Drugs, proteins, enzymes, antibodies, or nucleotides can bind to magnetic NPs and can be adsorbed at a specific site using magnetic field, or can be heated in alternating magnetic fields for use in hyperthermia. ${ }^{9}$ The synthesis of iron oxide NPs coated with biological molecules, eg, gluconic acid, lactobionic acid, or polyacrylic acid, through the most effective method of coprecipitation as compared to organic solvent heating method and/or polyol method are reported in the literature. ${ }^{28,82} \mathrm{NPs}$ of such types have narrow size distribution and are highly water soluble. They have great potential in numerous biomedical applications such as tissue engineering because of the biological coatings such as liposome coating. ${ }^{27,31,48}$ Due to hydrogen bond formation, these NPs also show hydrodynamic size in solution. ${ }^{83}$

Magnetic iron oxide particles have hydrophobic surfaces with a large surface-area-to-volume ratio in the absence of any surface coating material. These particles agglomerate and form large clusters due to hydrophobic interactions between the particles, resulting in increased particle size. These clusters then exhibit strong magnetic dipole-dipole attractions between them and show ferromagnetic behavior. ${ }^{84}$ Each of them comes into the magnetic field of the neighbor when two large-particle clusters approach one another. In addition to arousal of attractive forces between the particles, each particle is in the magnetic field of the neighbor and receives further magnetization. ${ }^{85}$ Mutual magnetization takes place due to adherence of remnant magnetic particles which results in the increased aggregation properties. ${ }^{9}$ Since particles are attracted magnetically, in addition to the usual flocculation due to van der Waals forces, surface modification is often indispensable. A high density coating is often desirable in order to stabilize the iron oxide NPs. To prevent the aggregation of the nanoscale particulate stabilizer, a surfactant or a polymer is usually added at the time of preparation. Most of these polymers adhere to surfaces in a substrate-specific manner. ${ }^{86}$ Table 3 shows different surface modifications and strategies for the fabrication of magnetic iron oxide NPs. ${ }^{9,87}$

Materials with polymeric coating can be classified as synthetic or natural. Examples of distinctive synthetic polymeric systems are: polyethylene glycol, poly(vinyl alcohol), poly(lactic-co-glycolic acid), poly(vinyl-pyrrolidone), poly(ethylene-co-vinyl acetate), etc. ${ }^{4}$ Natural polymer systems

Table 3 Different approaches for the preparation and surface modification of magnetic iron oxide NPs

\begin{tabular}{ll}
\hline Diameter (nm) & Approaches for the preparation and surface modification of magnetic iron oxide NPs \\
\hline I-20 & $\begin{array}{l}\text { Precipitation of magnetic iron oxide NPs in either solution or aqueous core of water in oil microemulsions. } \\
\text { Oxygen-free and lower temperature environment provide the SPIONs with high magnetization values } \\
\text { 20-30 (up to 50) }\end{array}$ \\
$\begin{array}{l}\text { Precipitation of magnetic iron oxide NPs in the presence of polymers or surfactants. } \\
\text { NPs obtained are monodispersed and fairly stable in solution }\end{array}$ \\
$\begin{array}{l}\text { Surface coating of magnetic iron oxide NPs with surfactants or polymers (core-shell structure). } \\
\text { Ferrofluids obtained are stable under in vivo and in vitro conditions, and also the particles could be derivatized with bioactive } \\
\text { molecules }\end{array}$
\end{tabular}

Note: Inside the aqueous droplets of reverse micelles, uniform and ultrasmall NPs can be fabricated

Abbreviations: NPs, nanoparticles; SPIONs, superparamagnetic iron oxide NPs. 
include the use of gelatin, pollutant, dextran chitosan, etc. ${ }^{88,89}$ In order to enhance dispersibility in an aqueous medium, various surfactants, such as sodium oleate, dodecylamine, and sodium carboxymethyl cellulose, are usually used. ${ }^{90}$ But, one should be careful about choosing the coating materials for the NPs. Table 4 shows the various summarized coating methods and materials. Some coating techniques are designed for protecting iron oxide cores from corrosion, and some are designed with additional chemical and physical functions for specific applications. ${ }^{13,31}$

According to the properties of magnetic NP cores, the experimental conditions vary from each other, eg, size, solubility, and surface chemistry. Several coating methods are considered for protecting iron oxide cores from corrosion, and some are premeditated with additional physical and chemical functions for their precise applications. Various typical coating techniques and materials to protect iron oxide cores from corrosion are summarized in Table 5. Table 5 also portrays some chemical and physical functions for the specific applications. ${ }^{31}$

\section{Characterization of magnetic NPs}

For a better understanding of surface properties, comprehensive surface characterization techniques are used such as surface morphology, chemical composition, and spatial distribution of the functional groups. ${ }^{102}$ Fundamental techniques employed to investigate magnetic NPs include: X-ray diffraction analysis, Fourier transform infrared spectroscopy, TEM, SEM, atomic force microscopy, X-ray photoelectron spectroscopy, vibrating sample magnetometry, and thermal gravimetric analysis. ${ }^{10}$ Other characterization techniques include ion-particle probe, thermodynamic, NP tracking analysis, tilted laser microscopy, zeta-potential measurements, isopycnic centrifugation, hydrophobic interaction chromatography, fieldflow fractionation, electrophoresis, and turbidimetry. ${ }^{103,104}$ Detailed properties, successfulness, and restrictions of each technique are summarized in Table 6.

\section{Factors enhancing the efficiency of iron oxide NPs}

- The most effective, cheap, and simplest pathway (technique) to obtain magnetic particles, eg, the simplest one is the precipitation technique to obtain iron oxide particles. ${ }^{105}$

- Cost-effectiveness of iron NP preparation technique (depends on the final product and its application), relatively higher cost of production is tolerable, eg, for high end use such as in drug delivery systems; however, it is necessary to use low-cost chemicals during the synthesis of a product that may be utilized in a less-sensitive exertion, eg, waste water mitigation from toxic ions. ${ }^{105}$

- Size of NPs, ie, small size gives a high surface-area-tovolume ratio that enables interaction with various types of chemical species, both aqueous and gaseous. ${ }^{106}$ The materials at nanoscale are potentially highly efficient for binding metal ions.

- Controlled shape, nucleation, growth, durability, reproducibility, scalability, dispersibility (particularly for building complex magnetic nanostructures). ${ }^{7,37,105,107}$ For example, the activation of iron oxide by changing its particle shape to expose its most active catalytic site could produce efficient and cheap catalysts for several reactions.

Table 4 Different coating molecules/polymers for magnetic NPs to stabilize ferrofluids

\begin{tabular}{|c|c|c|}
\hline Molecules/polymers & Benefits & References \\
\hline PEG & $\begin{array}{l}\text { Improves biocompatibility by noncovalent immobilization of PEG on the surface, internalization efficiency } \\
\text { of the NPs, and blood circulation time }\end{array}$ & 91 \\
\hline Dextran & Stabilizes the colloidal solution and increases the blood circulation time & 92 \\
\hline PVP & Stabilizes the colloidal solution and enhances the blood circulation time & 93 \\
\hline Fatty acids & Terminal functional carboxyl groups and colloidal stability & 94 \\
\hline PVA & Gives rise to monodisperse particles and prevents coagulation of particles & 95 \\
\hline Polyacrylic acid & Improves biocompatibility of the particles, also helps in bioadhesion, and increases the stability & 96 \\
\hline Polypeptides & Worthy for cytology, such as targeting to cell & 97 \\
\hline Phosphorylcholine & Coagulation activating and colloidal solution stabilizer & 98 \\
\hline Poly(d, l-lactide) & Low cytotoxicity and biocompatible & 48,99 \\
\hline PolyNIPAAM & Cell separation and drug delivery & 72 \\
\hline Chitosan & $\begin{array}{l}\text { A widely used natural cationic linear polymer as nonviral gene delivery system, is biocompatible, used in } \\
\text { medicine and food, applied in water treatment, polymers, textiles, biotechnology, hydrophilic, and used in } \\
\text { agriculture }\end{array}$ & 88,100 \\
\hline Gelatin & Biocompatible, natural polymer, emulsifier hydrophilic, and used as a gelling agent & 101 \\
\hline
\end{tabular}

Abbreviation: NPs, nanoparticles; PEG, polyethylene glycol; polyNIPAAM, poly(N-isopropylacrylamide); PVA, polyvinyl alcohol; PVP, polyvinyl pyrrolidone. 
Table 5 Summarization of various typical coating techniques and materials to protect iron oxide cores from corrosion

\begin{tabular}{|c|c|c|c|c|c|c|}
\hline S\# & $\begin{array}{l}\text { Coating } \\
\text { material }\end{array}$ & $\begin{array}{l}\text { Synthesizing } \\
\text { procedure }\end{array}$ & $\begin{array}{l}\text { Experimental } \\
\text { conditions }\end{array}$ & $\begin{array}{l}\text { Application/ } \\
\text { purpose }\end{array}$ & $\begin{array}{l}\text { Core-shell } \\
\text { form of FeO } \\
\text { NPs }\end{array}$ & Advantages \\
\hline I. & $\begin{array}{l}\text { Gold and/or } \\
\text { silver }\end{array}$ & $\begin{array}{l}\text { By reducing } \mathrm{Au} \text { or } \\
\mathrm{Ag} \text { precursor in the } \\
\text { presence of iron oxide } \\
\mathrm{NPs}\end{array}$ & $\begin{array}{l}\text { Differ according to } \\
\text { the properties of iron } \\
\text { oxide NP cores, such } \\
\text { as the solubility, surface } \\
\text { chemistry, and size }\end{array}$ & $\begin{array}{l}\text { Protect iron oxide } \\
\text { NPs from low pH } \\
\text { corrosion }\end{array}$ & $\begin{array}{l}\mathrm{Fe}_{3} \mathrm{O}_{4} / \mathrm{Au} \text { and/or } \\
\mathrm{Fe}_{3} \mathrm{O}_{4} / \mathrm{Au} / \mathrm{Ag}\end{array}$ & $\begin{array}{l}\text { Provide additional optical } \\
\text { properties. } \\
\text { Facilitate organic conjugation by } \\
\text { Gold-silver chemistry }\end{array}$ \\
\hline 2. & $\mathrm{SiO}_{2}$ & $\begin{array}{l}\text { By alkaline hydrolysis of } \\
\text { TEOS in the presence of } \\
\text { core NPs }\end{array}$ & $\begin{array}{l}\text { Changing reaction } \\
\text { conditions to either } \\
\text { porous or dense }\end{array}$ & $\begin{array}{l}\text { Colloid surface } \\
\text { modification }\end{array}$ & $\mathrm{Fe}_{3} \mathrm{O}_{4} / \mathrm{SiO}_{2}$ & $\begin{array}{l}\text { Compatible with many chemicals } \\
\text { and molecules for bioconjugations. } \\
\text { Small molecules such as dye and } \\
\text { drug, and even quantum dots can } \\
\text { be incorporated. } \\
\text { Covalently attaches to various } \\
\text { ligands and biomolecules to target } \\
\text { organs via antibody-antigen } \\
\text { recognition. } \\
\text { Stable and can be easily dispersed } \\
\text { in an aqueous or organic solution, } \\
\text { even without surfactants }\end{array}$ \\
\hline 3. & $\mathrm{TaO}_{x}$ & $\begin{array}{l}\text { By thermal } \\
\text { decomposition of iron } \\
\text { oleate precursor and fast } \\
\text { hydrolysis of } \mathrm{TaO}_{x}\end{array}$ & $\begin{array}{l}\text { In a mixture of lgepal } \\
\mathrm{CO}-520, \mathrm{NaOH} \text {, and } \\
\text { other organic solvents }\end{array}$ & $\begin{array}{l}\text { Clinical applications. } \\
\text { CT for imaging } \\
\text { newly formed } \\
\text { blood vessels in } \\
\text { the tumors, while } \\
\text { MRI detects tumor } \\
\text { microenvironment }\end{array}$ & $\mathrm{Fe}_{3} \mathrm{O}_{4} / \mathrm{TaO}_{x}$ & $\begin{array}{l}\text { Low-cost CT contrast agent. } \\
\text { Bifunctional agent for CT and } \\
\text { MRI. } \\
\text { Potential for accurate diagnosis } \\
\text { of cancer }\end{array}$ \\
\hline 4 & $\begin{array}{l}\text { Polymer } \\
\text { (both } \\
\text { natural and } \\
\text { synthetic) }\end{array}$ & $\begin{array}{l}\text { By polymerization } \\
\text { of precursors in the } \\
\text { presence of iron oxide } \\
\text { NPs }\end{array}$ & $\begin{array}{l}\text { Similar to the } \\
\text { hydrolysis synthesis of } \\
\text { silica-coated } \mathrm{Fe}_{3} \mathrm{O}_{4} \mathrm{NPs}\end{array}$ & $\begin{array}{l}\text { To enhance } \\
\text { dispersibility in an } \\
\text { aqueous medium }\end{array}$ & $\begin{array}{l}\mathrm{Fe}_{3} \mathrm{O}_{4} \text { and } \\
\mathrm{CdSe} / \mathrm{ZnS} \mathrm{NPs} \\
\text { incorporated } \\
\text { into the PLGA } \\
\text { matrix }\end{array}$ & $\begin{array}{l}\text { Gives a protective and } \\
\text { biocompatible organic surface for } \\
\text { functionalization }\end{array}$ \\
\hline 5 & $\begin{array}{l}\text { Small } \\
\text { molecules }\end{array}$ & $\begin{array}{l}\text { By thermal } \\
\text { decomposition of } \\
\mathrm{Fe}(\mathrm{CO})_{5} \text {. } \\
4-\mathrm{MC} \text { employed as } \\
\text { surfactants, which could } \\
\text { be directly conjugated } \\
\text { with a peptide, } \\
\text { c(RGDyK), through the } \\
\text { Mannich reaction }\end{array}$ & Oxidation under air & $\begin{array}{l}\text { To avoid a large } \\
\text { hydrodynamic size }\end{array}$ & $\begin{array}{l}\mathrm{c}(\mathrm{RGDyK})- \\
\mathrm{MC}-\mathrm{Fe}_{3} \mathrm{O}_{4}\end{array}$ & $\begin{array}{l}\text { Stable. } \\
\text { Target specifically to integrin } \\
\text { avb3-rich tumor cells. } \\
\text { Enhanced the MRI contrast for } \\
\text { tumor cell detection. } \\
\text { RGD-coated } \mathrm{Fe}_{3} \mathrm{O}_{4} \mathrm{NPs} \text { were } \\
\text { found stable in aqueous solution } \\
\text { for months }\end{array}$ \\
\hline 6 & Carbon & $\begin{array}{l}\text { Carbonization of } \\
\text { hydrocarbon precursors. } \\
\text { By a CVD method at } \\
800^{\circ} \mathrm{C} \text { under nitrogen } \\
\text { gas protection }\end{array}$ & $\begin{array}{l}\text { High temperature } \\
\text { annealing that needs to } \\
\text { be lowered to optimize } \\
\text { the process }\end{array}$ & $\begin{array}{l}\text { Gives cytotoxicity } \\
\text { results }\end{array}$ & $\begin{array}{l}\text { Carbon-coated } \\
\mathrm{FeCo} \text { and/or } \\
\mathrm{Fe}_{3} \mathrm{O}_{4}\end{array}$ & $\begin{array}{l}\text { Cells can uptake both single NPs } \\
\text { and small NP clusters, which affect } \\
\text { the evaluation of the cytotoxicity }\end{array}$ \\
\hline
\end{tabular}

Note: Also shows some chemical and physical functions for their specific applications.

Abbreviations: CVD, chemical vapor deposition; CT, computed tomography; 4-MC, 4-methylcatechol; MRI, magnetic resonance imaging; NPs, nanoparticles; PLGA, poly(lactic-co-glycolic acid); RGD, arginylglycylaspartic acid; TEOS, tetraethyl orthosilicate; $\mathrm{S}$ \#, serial number.

- Tailoring the composition of iron oxides, selective adsorption of different metal ions can also be induced. Iron oxide NPs are now considered very attractive for the adsorption or recovery of metal ions from natural water streams or industrial wastes. ${ }^{108}$

- High magnetic susceptibility for an effective magnetic enhancement. ${ }^{23}$ Further, the diameter of coated (with metallic or nonmetallic) iron oxide NPs is prone to tailoring, and the indispensible diameter can be attained by adjusting reduction and the repeat times. ${ }^{105}$

- Characteristics associated with the use of magnetically responsive and magnetically guided NPs in magnetofection and drug delivery. ${ }^{72}$

- Particles should be nanosized (6-15 nm; particles below $15 \mathrm{~nm}$ would consist of a single magnetic field, ie, a particle that is in a state of uniform magnetization and has 
Table 6 The analytical techniques for the assessment of the physicochemical properties of NMs

\begin{tabular}{|c|c|c|c|}
\hline Modalities & $\begin{array}{l}\text { Analyzed physical and } \\
\text { chemical properties }\end{array}$ & Successfulness & Restrictions \\
\hline DLS & $\begin{array}{l}\text { Size distribution based on } \\
\text { hydrodynamic. }\end{array}$ & $\begin{array}{l}\text { Constructive way for rapid and more consistent } \\
\text { measurement. } \\
\text { Measures in some liquid media, solvent of interest } \\
\text { for monodisperse, hydrodynamic sizes are exactly } \\
\text { determined. } \\
\text { Moderate expenses on equipment. }\end{array}$ & $\begin{array}{l}\text { With a particular composition, unresponsive } \\
\text { correlation of size fractions. } \\
\text { Effect of small numbers of large particles in } \\
\text { polydisperse sample. } \\
\text { Size restrictions. } \\
\text { Restricted size determination. } \\
\text { Possibility of samples, spherical in shape. }\end{array}$ \\
\hline FCS & $\begin{array}{l}\text { Dimension, binding kinetics } \\
\text { of hydrodynamic. }\end{array}$ & $\begin{array}{l}\text { High temporal and spatial magnification. } \\
\text { Uptake sample is low. } \\
\text { For studying concentration effect, molecular } \\
\text { diffusion, chemical kinetics, and conformation } \\
\text { dynamics are specifically performed via fluorescent } \\
\text { probes methods. }\end{array}$ & $\begin{array}{l}\text { Due to deficiency of proper methods, it causes } \\
\text { limitation in fluorophore species and restriction in } \\
\text { usage and inaccuracy. }\end{array}$ \\
\hline & $\begin{array}{l}\text { Size distribution and } \\
\text { hydrodynamic size. }\end{array}$ & $\begin{array}{l}\text { No need of sample preparation. } \\
\text { Complementary data obtained from IR }\end{array}$ & $\begin{array}{l}\text { Compared to Rayleigh scattering, there is } \\
\text { comparatively a weak single restricted spatial }\end{array}$ \\
\hline TERS & $\begin{array}{l}\text { Conformational variations } \\
\text { in structural, chemical, } \\
\text { conjugate and electronic } \\
\text { characteristics. }\end{array}$ & $\begin{array}{l}\text { Capability of detecting tissue abnormality. } \\
\text { Improved Raman scattering signal. } \\
\text { SERS. } \\
\text { Enhanced spatial resolution of the NMs. } \\
\text { Topological information. }\end{array}$ & $\begin{array}{l}\text { resolution, enormously minute cross-section. } \\
\text { Disturbance of fluorescence irreproducible } \\
\text { measurement. }\end{array}$ \\
\hline $\begin{array}{l}\text { Zeta- } \\
\text { potential }\end{array}$ & $\begin{array}{l}\text { Stability concerning to } \\
\text { charge on surface }\end{array}$ & Concurrent measurement of numerous particles. & $\begin{array}{l}\text { Electro-osmotic effect deficiency of accurate and } \\
\text { repetition measurement. }\end{array}$ \\
\hline NSOM & NMs, shapes and size. & $\begin{array}{l}\text { Sudden measurement of fluorescence and } \\
\text { spectroscopy. } \\
\text { Close situation analysis. } \\
\text { Nanoscaled surface categorization of chemical } \\
\text { information and interactions at nanoscaled } \\
\text { declaration. }\end{array}$ & $\begin{array}{l}\text { Lengthy scanning time. } \\
\text { Analysis of minute sample area. } \\
\text { Intensity of incident light is deficient to stimulate } \\
\text { delicate fluorescent molecules. } \\
\text { Problems in visualization of soft materials. } \\
\text { Analysis restriction toward the NM surface. }\end{array}$ \\
\hline$C D$ & $\begin{array}{l}\text { In biomolecules. } \\
\text { Structural and } \\
\text { conformational variations } \\
\text { (such as DNA and protein). } \\
\text { Thermal constancy. }\end{array}$ & Constructive and motivated methods. & $\begin{array}{l}\text { Conformational fluctuations are due to the } \\
\text { involvement of nonspecific residue absorption. } \\
\text { Methods are more sensitive than this. } \\
\text { For nonchiral. } \\
\text { Chromophores, CD signals, are weak. } \\
\text { For analysis of molecules consisting of multiple chiral } \\
\text { chromophores facing challenges. }\end{array}$ \\
\hline MS & $\begin{array}{l}\text { Molecular weight. } \\
\text { Composition. } \\
\text { Structure. } \\
\text { Surface properties } \\
\text { (secondary ion MS). }\end{array}$ & $\begin{array}{l}\text { High accuracy and precision in measurement. } \\
\text { High sensitivity to detection (a very small amount } \\
\text { of sample required). }\end{array}$ & $\begin{array}{l}\text { Expensive equipment. } \\
\text { Lack of complete databases for the identification of } \\
\text { molecular species. } \\
\text { Limited application to date in studying NM } \\
\text { bioconjugates. }\end{array}$ \\
\hline $\begin{array}{l}\text { IR } \\
\text { ATR-FTIR }\end{array}$ & $\begin{array}{l}\text { Bioconjugate. } \\
\text { Surface properties } \\
\text { such as structure and } \\
\text { conformation. }\end{array}$ & $\begin{array}{l}\text { Rapid and cheap measurement. } \\
\text { No or minimal sample preparation demands. } \\
\text { Irrespective of sample thickness enhanced } \\
\text { reproducibility. }\end{array}$ & $\begin{array}{l}\text { Sample preparation (IR) is complex intervention and } \\
\text { efficient absorbance of water. } \\
\text { In nanoscale analysis sensitivity is comparatively low. }\end{array}$ \\
\hline $\begin{array}{l}\text { SEM } \\
\text { ESEM }\end{array}$ & $\begin{array}{l}\text { Size and size distribution. } \\
\text { Shape. } \\
\text { Aggregation. } \\
\text { Dispersion. }\end{array}$ & $\begin{array}{l}\text { Simultaneous measurement of the size navigation } \\
\text { and shape of NMs. } \\
\text { High deliration (below to subnanometer) in natural } \\
\text { state visualization of biomolecules supplied by the } \\
\text { usage of ESEM technique. }\end{array}$ & $\begin{array}{l}\text { Requirement of conducting sample or coating } \\
\text { conductive materials. } \\
\text { Need of dry samples. } \\
\text { In nonphysiological states, the sample analysis occurs. } \\
\text { Size distribution is based on biased statistics. } \\
\text { Heterogeneous samples are required. } \\
\text { Costly apparatus. } \\
\text { For numerous NP bioconjugates, cryogenic method } \\
\text { is needed. } \\
\text { ESEM resolution is reduced. }\end{array}$ \\
\hline
\end{tabular}

(Continued) 
Table 6 (Continued)

\begin{tabular}{|c|c|c|c|}
\hline Modalities & $\begin{array}{l}\text { Analyzed physical and } \\
\text { chemical properties }\end{array}$ & Successfulness & Restrictions \\
\hline TEM & $\begin{array}{l}\text { Shape heterogeneity. } \\
\text { Size and size navigation. } \\
\text { Dispersion. } \\
\text { Accumulation. }\end{array}$ & $\begin{array}{l}\text { With higher spatial resolution than SEM, direct } \\
\text { measurement of the size transportation and shape } \\
\text { of NMs occurs. } \\
\text { For investigation of chemical composition and } \\
\text { electronic structure of NMs. } \\
\text { A lot of analytical techniques are paired off with } \\
\text { TEM. }\end{array}$ & $\begin{array}{l}\text { Ultrathin samples are needed. } \\
\text { Requirement of samples in nonphysiological states. } \\
\text { Damage or variations in sample. } \\
\text { Sampling is insufficient. } \\
\text { Equipment is expensive. }\end{array}$ \\
\hline STM & $\begin{array}{l}\text { Shape heterogeneity. } \\
\text { Size and size navigation. } \\
\text { Dispersion. } \\
\text { Accumulation. }\end{array}$ & $\begin{array}{l}\text { Sudden measurement at atomic level, high, spatial } \\
\text { resolution takes place. }\end{array}$ & $\begin{array}{l}\text { Demand of conductive surfaces. } \\
\text { Electronic structure and surface topography } \\
\text { inevitably having an easy linkage with surface. }\end{array}$ \\
\hline AFM & $\begin{array}{l}\text { Shape heterogeneity. } \\
\text { Size and size navigation. } \\
\text { Dispersion. } \\
\text { Accumulation and sorption. }\end{array}$ & $\begin{array}{l}\text { Mapping of 3D sample surface resolution of sub- } \\
\text { nanoscaled topographic samples. } \\
\text { Direct measurement in dry state, ambient, or } \\
\text { aqueous environment. }\end{array}$ & $\begin{array}{l}\text { Lateral dimensions over description. } \\
\text { Sampling is poor and time consuming } \\
\text { The exterior of NM analysis is generally restricted. }\end{array}$ \\
\hline NMR & $\begin{array}{l}\text { Indirect analysis of size. } \\
\text { Structure purity. } \\
\text { Concentration. } \\
\text { Conformational variations. }\end{array}$ & $\begin{array}{l}\text { Noninvasive and constructive procedure. } \\
\text { Minute or less sample preparation required. }\end{array}$ & $\begin{array}{l}\text { Sensitivity is low. } \\
\text { Time wasting. } \\
\text { Comparatively large amount of sample needed. }\end{array}$ \\
\hline XRD & $\begin{array}{l}\text { For crystalline materials, } \\
\text { shape, size, and structure } \\
\text { determination. }\end{array}$ & $\begin{array}{l}\text { Well-organized modalities. } \\
\text { At atomic level, high spatial resolution. }\end{array}$ & $\begin{array}{l}\text { Usage in crystalline materials is reduced. } \\
\text { Only one binding or conformation site for sample; } \\
\text { accessibility compared to electron diffraction is low. }\end{array}$ \\
\hline SAXS & $\begin{array}{l}\text { Shape, structure, size, and } \\
\text { size transportation. }\end{array}$ & $\begin{array}{l}\text { Constructive procedure sample preparation is very } \\
\text { simple. } \\
\text { Accessibility of amorphous materials and sample in } \\
\text { solution. }\end{array}$ & Resolution is comparatively low. \\
\hline
\end{tabular}

Abbreviations: AFM, atomic force microscopy; ATR, attenuated total reflection; CD, circular dichroism; 3D, three dimension; DLS, dynamic light scattering; ESEM, environmental SEM; FCS, fluorescence correlation spectroscopy; FTIR, Fourier transform infrared; IR, infrared; MS, mass spectroscopy; NM, nanomaterial; NMR, nuclear magnetic resonance; NPs, nanoparticles; NSOM, near-field scanning optical microscopy; RS, Raman scattering; SAXS, small-angle X-ray scattering; SEM, scanning electron microscopy; SERS, surface-enhanced Raman scattering; STM, scanning tunneling microscopy; TEM, transmission electron microscopy; TERS, tip-enhanced Raman spectroscopy; XRD, X-ray diffraction analysis.

high saturation magnetization values. ${ }^{109}$ These nanosized range particles are rapidly removed through eructation and renal clearance. ${ }^{110}$

- The property of superparamagnetic crystal suspension to absorb energy of an oscillating magnetic field. This energy can be converted into heat for destroying the pathological tissue or cells (in vivo) by hyperthermia, since the tumor cells are more sensitive to high temperature as compared to healthy ones. ${ }^{111}$

- Tailored surface chemistry for specific biomedical applications. ${ }^{112}$

- Development of iron oxide NPs that should be characteristically suitable for optimal cell labeling and efficient MRI. There is a need to formulate standard procedures to control and compare different NPs in terms of cytotoxic effects and uptake efficiency. The effects of iron oxide NPs should be carefully evaluated on cultured cells prior to assessing their clinical potential in cell transplantation research. ${ }^{27,48,99,113}$
- Yielding efficient and cheap catalysts for various reactions by activating and changing the shapes of magnetic NPs that could expose their most active catalytic site. ${ }^{114}$

- High coactivity and low Curie temperature. ${ }^{2}$

\section{Applications of iron oxide NPs}

Iron oxide NPs due to their strong magnetic properties were used first in biology and then in medicine for the magnetic separation of biological products and cells as well as magnetic guidance of particle systems for site-specific drug delivery. ${ }^{72,115}$ The surface chemistry, size, and charge of magnetic particles influence biodistribution of the NPs. ${ }^{11}$ Activities in the clinical applications, in the past decades, of magnetic carriers and particles are increasing due to their role in diagnostics and treatment modalities. ${ }^{83}$ Magnetic NPs have attracted much interest as a labeling material in life sciences and various other major fields of the scientific world. ${ }^{116}$ Some well-known fields with the possible applications of magnetic NMs are summarized in Table 7. 
Table 7 The main fields where magnetic NMs have been employed

\begin{tabular}{|c|c|c|}
\hline Fields & Applications of magnetic NPs & References \\
\hline Biomedical & $\begin{array}{l}\text { Magnetic NPs (particularly coated with liposomes) for drug delivery, magnetic hyperthermia, MRI contrast agent, } \\
\text { magnetic separation, controlled drug release, cellular therapy, eg, cell labeling, tissue repair, cell separation } \\
\text { and handling of cells, purifying cell populations, magnetofection, diseases of the musculoskeletal system, severe } \\
\text { inflammation, disability, and pain }\end{array}$ & $9,31,99,113$ \\
\hline Health care & $\begin{array}{l}\text { Therapeutic targets in chemotherapy (cancer and tumor); nanoscale biosensors and imaging; nanocoatings } \\
\text { on surfaces; implants; nanocarrier for vaccination; antimicrobial activities; SLN in drug delivery and research; } \\
\text { nanophotothermolysis with pulsed lasers for the treatment of cancer, hepatitis B virus, respiratory syncytial virus, } \\
\text { influenza virus, antiviral agents against HIV-I, monkeypox virus, herpes simplex virus type I, and Tacaribe virus; } \\
\text { delivering antigens for a particular disease into the blood stream; preventing aging of the skin }\end{array}$ & $\begin{array}{l}9,15,27,105 \\
117\end{array}$ \\
\hline $\begin{array}{l}\text { Agriculture and } \\
\text { food }\end{array}$ & $\begin{array}{l}\text { Nano-based products (nanofertilizers, nanofungicides, nanopesticides), engineered NPs, and CNTs boost } \\
\text { crop yields; pyrite NPs are used as a seed treatment for various plants prior to sowing the seeds. Broader } \\
\text { leaf morphology, larger leaf numbers, increased biomass. Enhanced breakdown of stored starch. This raises } \\
\text { the possibility of developing iron pyrite NPs as a commercial seed treatment agent (pro-fertilizer). The } \\
\text { strategy is safe, as the process does not put NPs into the soil. Reduced dose requirement as compared to } \\
\text { chemical fertilizers. No adverse effects on plant growth. Nanosensors, nanofood, encapsulation, food packing, } \\
\text { nanocoatings, precision farming (remote-sensing devices), nanocomposites, gene transfer (crop improvement), } \\
\text { and nanoporous membranes }\end{array}$ & $\begin{array}{l}14,116,118 \\
119\end{array}$ \\
\hline $\begin{array}{l}\text { Environmental } \\
\text { remediation }\end{array}$ & $\begin{array}{l}\text { Pollution prevention (detection, monitoring, and remediation). Waste water treatment (permeable reactive } \\
\text { barriers, membrane filtration, adsorption). Catalyst coatings such as palladium (Pd), climate change (carbon } \\
\text { capture), artificial leaf for } \mathrm{CO}_{2} \text { sequestration, mineral carbonation, biomimetic carbonation, } \mathrm{N}_{2} \mathrm{O} \text { decomposition, } \\
\text { methane combustion. Improves manufacturing processes (efficiency, waste reduction), dematerialization } \\
\text { (reduction in material quantity), sensing (pollutant sensors, nanoporous membranes, chemical and bio- } \\
\text { nanosensors, nanowire sensor for explosives), and energy (heat distribution, eg, ceramic-like materials that } \\
\text { provide sufficient reliability and durability of the entire structure) }\end{array}$ & $\begin{array}{l}|5,73,1| 1, \\
|20,12|\end{array}$ \\
\hline Energy & $\begin{array}{l}\text { Photovoltaic film coatings, improved efficiency of fuel production and consumption, fuel cells and batteries, } \\
\text { nanobioengineering of enzymes, thermoelectric materials, and prototype solar panels, batteries, aerogels, } \\
\text { conversion of waste heat in computers, automobiles, homes, power plants, etc, to usable electrical power }\end{array}$ & $4,122,123$ \\
\hline $\begin{array}{l}\text { Defense and } \\
\text { aerospace }\end{array}$ & Nanocomposites, nanocoatings, sensors and electronics, fuel additives and energy devices, and smart materials & $124-126$ \\
\hline Construction & $\begin{array}{l}\text { Nanocoatings, nanocomposites, nanoscale sensors, smart materials, and additives to concrete. Iron oxide } \\
\text { pigments are used in coloring concrete, brick, tile, and other construction materials }\end{array}$ & 127,128 \\
\hline Automotive & Additives in catalysts and lubricants, nanocoatings, fuel cells, composite fillers, and smart materials & 129,130 \\
\hline Textiles & Sensors, nanofibers, coatings, and smart materials & $|3|, \mid 32$ \\
\hline Electronics & Printed electronics, carbon nanotubes, nanoscale memory, nanowires, NEMS, spintronics, and quantum dots & $124,133,134$ \\
\hline
\end{tabular}

Abbreviations: CNTs, carbon nanotubes; MRI, magnetic resonance imaging; NEMS, nanoelectromechanical systems; NPs, nanoparticles; SLN, solid lipid NPs.

\section{Biodistribution and bioelimination of iron NPs}

Currently, iron oxide NPs have wide applications in various fields such as in medical sciences, whereas a lower number of studies report uptake and biodistribution of iron NPs (Figure 3). Size, shape, and surface characterization of iron NPs determine their biological distribution ${ }^{135}$ and can involve opsonization (serum protein interaction) and particle cell interaction. ${ }^{136}$ Various biodistributation studies report blood, spleen, liver, and kidney as probable localization for the NPs, and preferentially accumulation occurs in liver and spleen. ${ }^{137}$ Recent studies report that ultrasmall iron oxide NPs can be used as potent MRI contrast agents. ${ }^{27,138}$ This MRI system is very important in the visualization of bioevents, such as gene expression, and metastasis at cellular and subcellular levels. ${ }^{139}$
NP levels along with biodistribution data show that both kidney and liver are involved in NP elimination (Figure 3). Recently, it has been reported that after 6 hours of injection $>50 \%$ of iron is found in liver. ${ }^{79}$ These studies suggest the involvement of reticular endothelial system in the clearance of NPs and major problem in biomedical application of these particles. ${ }^{137}$ Higher vascularization and permeability of iron NPs are responsible for their uptake by reticular endothelial system ${ }^{140}$ and macrophage. Opsonization is one of the important processes for the elimination of magnetic NPs from circulation through liver macrophages. ${ }^{141,142}$ In different studies, magnetic NP accumulation has also been reported in lungs due to vascularized and monocyte-rich nature. ${ }^{137}$ Chaves et al ${ }^{143}$ reported the accumulation of magnetic NPs in the lungs of mice for up to 3 months and found no associated toxicity. Normally the human body contains: hemoglobin protein, myoglobin, 


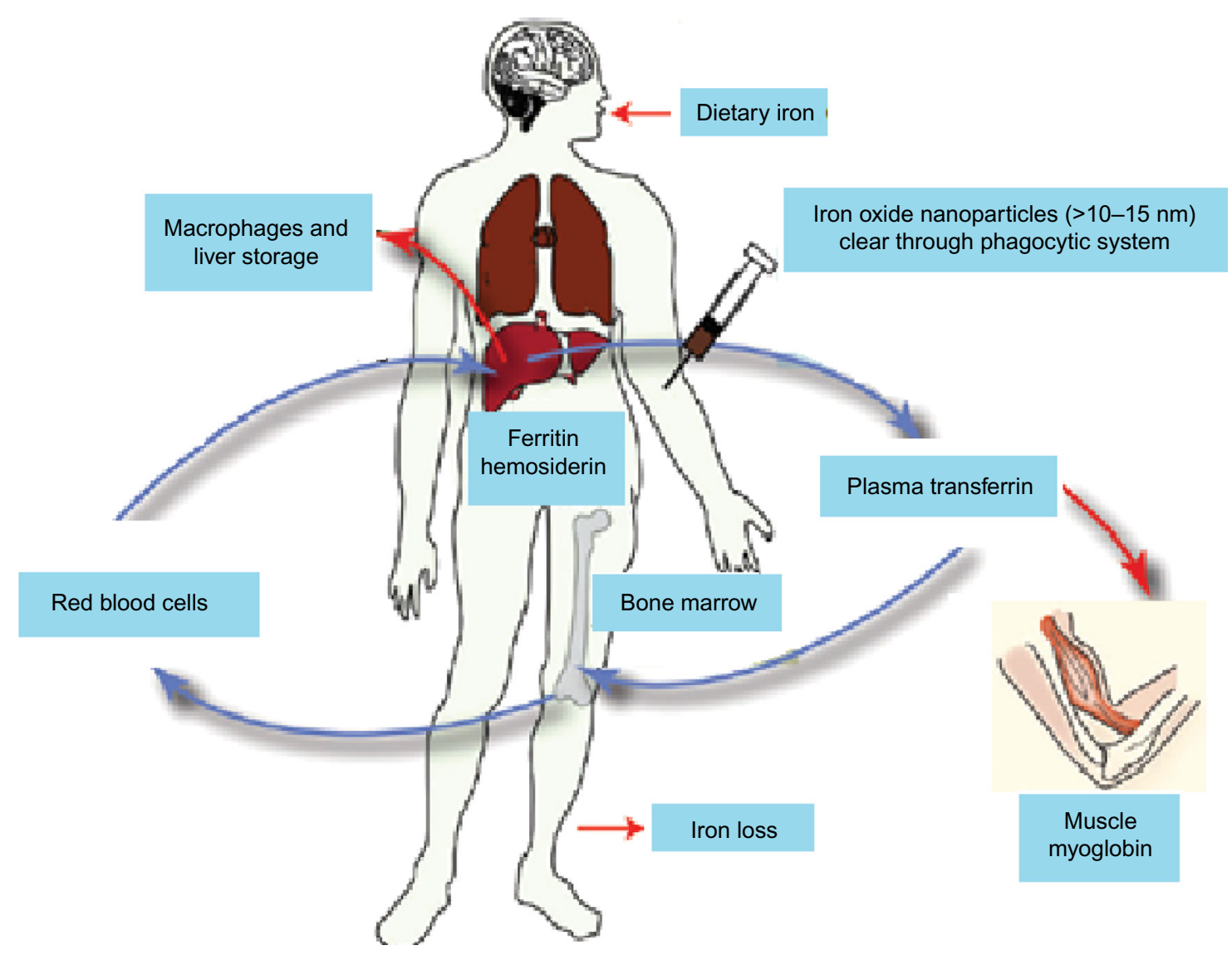

Figure 3 General pathway showing metabolism, transport, and biodegradation of iron oxide NPs.

Abbreviation: NPs, nanoparticles.

transferrin, and ferritin at $65 \%, 4 \%, 0.1 \%$, and $15 \%-30 \%$ of magnetic NPs, respectively. It is believed that the degradation of iron oxide NPs occurs similarly like ferritins at molecular level. ${ }^{137}$ The degradation of iron NPs leads to increase in the iron level in the organs. Iron level is regulated by two main iron-protein complexes, ferritin and transferrin, which are involved in storing and shuttling of iron ions. ${ }^{144}$ Nissim and Robson $^{145}$ and Richter ${ }^{146}$ are the founding researchers who reported the in vivo biodegradation of iron oxide particles along with the role of ferritin and transferrin in the biodistribution of degradation products.

Mononuclear phagocytic system degrades the intravenously administered NP (>15 nm). Hemosiderin and ferritin generate iron-protein complexes. Transferrin can also be generated from ferritin and transported to bone marrow as a precursor of hemoglobin. Myoglobin is also an important iron-protein complex involved in oxygen transport in the muscle. Insubstantial and aged red blood cells burst in the spleen and release hemoglobin that results in enrichment of iron content. Macrophages metabolize hemoglobin into ferritin that is stored in hepatocytes or converted to transferrin used in the synthesis of red blood cells.

\section{Concerns for the application of NPs}

Nanotechnology is the science that involves the control of atoms and molecules to create new materials with a variety of useful functions, including many that could be exceptionally beneficial in many fields. ${ }^{147}$ The basic challenges fronting in the fabrication of convenient NPs for biologics include the means to achieve monodispersity, controlled shape and size, reproducibility, scalability, and building complex nanostructures. ${ }^{107} \mathrm{NMs}$ are very costly to produce as compared to more traditional materials, but greater quantities are produced, and according to normal economic principles their unit cost of production can be decreased, hence their price decreases. ${ }^{148}$ Since the properties of NPs are not easily understood and predicted, there are some concerns associated with human beings and agriculture which are given in Table 8 .

\section{Conclusion and perspectives}

Substantial progress has been made in the synthesis of monodisperse iron oxide NPs for application in nanobiotechnology. Various facile methods are in the progress of rapid development, offering different kinds of monodis- 
Table 8 Concerns and prospects of iron oxide nanoparticles associated with human beings and agriculture

\begin{tabular}{|c|c|c|c|c|}
\hline \multicolumn{2}{|c|}{ Implications for the health of humans } & \multicolumn{2}{|l|}{ Agriculture } & \multirow[t]{2}{*}{ References } \\
\hline Source & Effects & Source & Effects & \\
\hline $\begin{array}{l}\text { Orally inhaled } \\
\text { or ingested }\end{array}$ & $\begin{array}{l}\text { Proposed harmful side effects, I5, I49, } 150 \\
\text { lung cancer }\end{array}$ & Agrichemicals & $\begin{array}{l}\text { Seed germination and growth, affect soil } \\
\text { nutrients, harms bacteria important for } \\
\text { plant growth }\end{array}$ & $\mid 18,151,152$ \\
\hline Skin absorption & Irritation, skin cancer & NPs, eg, $\mathrm{CeO}$ & $\begin{array}{l}\text { Complete inhibition of the plants' ability to } \\
\text { fix nitrogen in the roots }\end{array}$ & \\
\hline Catalysis & $\begin{array}{l}\text { Speeds up reactions, illness, } \\
\text { or death }\end{array}$ & Environmental & $\begin{array}{l}\text { Airborne particles affect plants, loss of soil } \\
\text { fertility }\end{array}$ & \\
\hline $\begin{array}{l}\text { Absorption in } \\
\text { microbes }\end{array}$ & $\begin{array}{l}\text { Toxic effects upon ingestion or } \\
\text { inhalation, kills useful microbes } \\
\text { and nonbacterial cells }\end{array}$ & $\begin{array}{l}\text { Cosmetics industry } \\
\text { (ZnO NPs) }\end{array}$ & $\begin{array}{l}\text { Contaminant in solid waste from sewage } \\
\text { treatment, and are used as organic } \\
\text { fertilizers }\end{array}$ & \\
\hline
\end{tabular}

Abbreviations: $\mathrm{CeO}$, cerium oxide; MRI, magnetic resonance imaging; NM, nanomaterial; NPs, nanoparticles.

persed spherical nanocrystals with controllable particle sizes, compositions, shape, and magnetic properties. Owing to the biological environment, iron oxide soluble in an aqueous solution and in colloidal form is the main consideration when selecting synthesis methods. So the wet-chemical methods, such as coprecipitation and thermal decomposition of organometallic precursors, satisfy this requirement. Although coprecipitation can make watersoluble iron oxide NPs directly, the slow crystallization and the lack of size control restrict its use. A shortcoming of iron oxide NPs is their hydrophobic surface chemistry, which makes them merely soluble in nonpolar solvents such as toluene and hexane. Much effort in the past few years has been made in altering iron oxide NP surface chemistry to hydrophilic and biocompatible. A major challenge for all the methods is the design of magnetic NPs with effective surface coatings that provide optimum performance in in vitro and in vivo biological applications. Typical surface modification techniques of various kinds are summarized, including noble polymer coating, small molecular coating, silica coating, metal coating, and liposome coating. Further challenges include toxicity, scale-up, and safety of largescale particle production processes.

Monolayer polymer coating and organic ligand coating have successfully been converted hydrophobic nature into water soluble and biocompatible. Other than this, iron NPs coated with other biomolecules have enhanced their biocompatibility gaining them approval by authorities such as the US Food and Drug Administration. Therefore, the iron NPs are routinely used in the fields of MRI, targetspecific drug delivery, gene therapy, cancer treatments, in vitro diagnostics, and many more. Although magnetic NPs exhibit many distinctive properties, more toxicological research is needed and the criteria to evaluate toxicity should be clearly defined. The use of better and faster methods to develop our understanding of NP toxicity will advance the field. Moreover, the biocompatibility of iron NPs is linked with toxicity and biodegradation capability and this situation varies when surface is modified with other molecules which off course will effect biodistribution and bioaccumulation. The successful engineering of multifunctional NPs would be of particular interest for the development of theranostic nanomedicine. However, the challenge remains in the clinical translation of NP probes and in issues such as biocompatibility, toxicity, and in vivo and in vitro targeting efficiency.

\section{Disclosure}

The authors report no conflicts of interest in this work.

\section{References}

1. Salata OV. Applications of nanoparticles in biology and medicine. J Nanobiotechnology. 2004;2(1):3.

2. Huber DL. Synthesis, properties, and applications of iron nanoparticles. Small. 2005;1(5):482-501.

3. Cornell RM, Schwertmann U. The Iron Oxides: Structure, Properties, Reactions, Occurrences and Uses. 2nd ed. John Wiley \& Sons; 2006.

4. Laurent S, Forge D, Port M, et al. Magnetic iron oxide nanoparticles: synthesis, stabilization, vectorization, physicochemical characterizations, and biological applications. Chem Rev. 2008;108(6): 2064-2110.

5. Teja AS, Koh P-Y. Synthesis, properties, and applications of magnetic iron oxide nanoparticles. Prog Crystal Growth Char Mat. 2009;55(1):22-45.

6. De Cuyper M, Joniau M. Magnetoliposomes. Eur BiophysJ. 1988;15(5): 311-319.

7. Hasany S, Ahmed I, Rajan J, Rehman A. Systematic review of the preparation techniques of iron oxide magnetic nanoparticles. Nanosci Nanotechnol. 2012;2(6):148-158.

8. Wang C-T, Ro S-H. Nanocluster iron oxide-silica aerogel catalysts for methanol partial oxidation. Appl Catal A Gen. 2005;285(1): 196-204.

9. Gupta AK, Gupta M. Synthesis and surface engineering of iron oxide nanoparticles for biomedical applications. Biomaterials. 2005;26(18):3995-4021. 
10. Xu J, Sun J, Wang Y, Sheng J, Wang F, Sun M. Application of iron magnetic nanoparticles in protein immobilization. Molecules. 2014;19(8): 11465-11486.

11. Fortin JP, Wilhelm C, Servais J, Ménager C, Bacri JC, Gazeau F. Size-sorted anionic iron oxide nanomagnets as colloidal mediators for magnetic hyperthermia. JAm Chem Soc. 2007;129(9):2628-2635.

12. Naseem T, Farrukh MA. Antibacterial activity of green synthesis of iron nanoparticles using Lawsonia inermis and Gardenia jasminoides leaves extract. J Chem. 2015;2015:7.

13. Sheng-Nan $\mathrm{S}$, Chao W, Zan-Zan Z, et al. Magnetic iron oxide nanoparticles: synthesis and surface coating techniques for biomedical applications. Chinese Phys B. 2014;23(3):037503.

14. Siddiqui MH, Al-Whaibi MH, Sakran AM, et al. Calcium-induced amelioration of boron toxicity in radish. J Plant Growth Regul. 2013;32(1):61-71.

15. Auffan M, Rose J, Bottero JY, Lowry GV, Jolivet JP, Wiesner MR. Towards a definition of inorganic nanoparticles from an environmental, health and safety perspective. Nat Nanotechnol. 2009;4(10):634-641.

16. Khodakovskaya MV, de Silva K, Nedosekin DA, et al. Complex genetic, photothermal, and photoacoustic analysis of nanoparticleplant interactions. Proceedings of the National Academy of Sciences. 2011;108(3):1028-1033.

17. Allen M, Willits D, Mosolf J, Young M, Douglas T. Protein cage constrained synthesis of ferrimagnetic iron oxide nanoparticles. $A d v$ Mater Deerfield. 2002;14(21):1562-1565.

18. Feizi H, Rezvani Moghaddam P, Shahtahmassebi N, Fotovat A. Impact of bulk and nanosized titanium dioxide (TiO2) on wheat seed germination and seedling growth. Biol Trace Elem Res. 2012;146(1):101-106.

19. Ma Y, Kuang L, He X, et al. Effects of rare earth oxide nanoparticles on root elongation of plants. Chemosphere. 2010;78(3):273-279.

20. Luborsky F. The kinetics of growth of spherical iron crystallites in mercury. J Phys Chem. 1957;61(10):1336-1340.

21. Collier J, Messersmith P. Biomimetic mineralization, mesoporous structures. In Encyclopedia Mater Sci Technol. Elsevier. 2001:602-606.

22. Cuenya BR. Synthesis and catalytic properties of metal nanoparticles: size, shape, support, composition, and oxidation state effects. Thin Solid Films. 2010;518(12):3127-3150.

23. $\mathrm{Wu} \mathrm{W}, \mathrm{He} \mathrm{Q}$, Jiang C. Magnetic iron oxide nanoparticles: synthesis and surface functionalization strategies. ChemInform. 2009;40(24):i.

24. Wu S, Sun A, Zhai F, et al. $\mathrm{Fe}_{3} \mathrm{O}_{4}$ magnetic nanoparticles synthesis from tailings by ultrasonic chemical co-precipitation. Mat Lett. 2011;65(12):1882-1884

25. Narayanan KB, Sakthivel N. Biological synthesis of metal nanoparticles by microbes. Adv Colloid Interface Sci. 2010;156(1-2):1-13.

26. Maity D, Agrawal D. Synthesis of iron oxide nanoparticles under oxidizing environment and their stabilization in aqueous and non-aqueous media. J Magn Magn Mater. 2007;308(1):46-55.

27. Soenen SJ, Himmelreich U, Nuytten N, Pisanic TR 2nd, Ferrari A, De Cuyper M. Intracellular nanoparticle coating stability determines nanoparticle diagnostics efficacy and cell functionality. Small. 2010;6(19):2136-2145.

28. ElBayoumi TA, Torchilin VP, Weissig V. Liposomes: Methods and Protocols, Volume 1: Pharmaceutical Nanocarriers. 2010.

29. Xu J, Yang H, Fu W, et al. Preparation and magnetic properties of magnetite nanoparticles by sol-gel method. J Magn Magn Mater. 2007;309(2):307-311.

30. Lin X-M, Samia AC. Synthesis, assembly and physical properties of magnetic nanoparticles. J Magn Magn Mater. 2006;305(1):100-109.

31. Soenen SJ, Brisson AR, De Cuyper M. Addressing the problem of cationic lipid-mediated toxicity: the magnetoliposome model. Biomaterials. 2009;30(22):3691-3701.

32. Woo K, Hong J, Choi S, et al. Easy synthesis and magnetic properties of iron oxide nanoparticles. Chem Mat. 2004;16(14):2814-2818.

33. Salazar-Alvarez G, Muhammed M, Zagorodni AA. Novel flow injection synthesis of iron oxide nanoparticles with narrow size distribution. Chem Eng Sci. 2006;61(14):4625-4633.
34. Ling D, Hyeon T. Chemical design of biocompatible iron oxide nanoparticles for medical applications. Small. 2013;9(9-10):1450-1466.

35. Unsoy G, Yalcin S, Khodadust R, Gunduz G, Gunduz U. Synthesis optimization and characterization of chitosan-coated iron oxide nanoparticles produced for biomedical applications. J Nanopart Res. 2012;14(11):1-13.

36. Thorek DL, Chen AK, Czupryna J, Tsourkas A. Superparamagnetic iron oxide nanoparticle probes for molecular imaging. Ann Biomed Eng. 2006;34(1):23-38.

37. LaMer VK, Dinegar RH. Theory, production and mechanism of formation of monodispersed hydrosols. J Am Chem Soc. 1950;72(11): 4847-4854.

38. Jolivet J-P, Henry M, Livage J. Metal Oxide Chemistry and Synthesis: From Solution to Solid State. Wiley-Blackwell; 2000.

39. Kim D, Zhang Y, Voit W, Rao KV, Muhammed M. Synthesis and characterization of surfactant-coated superparamagnetic monodispersed iron oxide nanoparticles. J Magn Magn Mater. 2001;225(1):30-36.

40. Kim DK, Mikhaylova M, Zhang Y, Muhammed M. Protective coating of superparamagnetic iron oxide nanoparticles. Chem Mat. 2003;15(8):1617-1627.

41. Mohapatra S, Misra M, Mahajan VK, Raja KS. A novel method for the synthesis of titania nanotubes using sonoelectrochemical method and its application for photoelectrochemical splitting of water. $J$ Catal. 2007;246(2):362-369.

42. Cornell RM, Schwertmann U. The Iron Oxides: Structure, Properties, Reactions, Occurrences and Uses. 1st ed. John Wiley \& Sons; 2003.

43. Massart R. Preparation of aqueous magnetic liquids in alkaline and acidic media. IEEE Trans Magn. 1981;17(2):1247-1248.

44. Massart R, Cabuil V. Effect of some parameters on the formation of colloidal magnetite in alkaline-medium-yield and particle-size control. J de Chimie Physique et de Physico-Chimie Biologique. 1987;84(7-8): 967-973.

45. Tavakoli A, Sohrabi M, Kargari A. A review of methods for synthesis of nanostructured metals with emphasis on iron compounds. Chem Papers. 2007;61(3):151-170.

46. Pileni M. Reverse micelles as microreactors. J Phys Chem. 1993;97(27): 6961-6973.

47. Salazar Alvarez G. Synthesis, Characterisation and Applications of Iron Oxide Nanoparticles. 2004.

48. Soenen SJ, De Cuyper M. Assessing cytotoxicity of (iron oxidebased) nanoparticles: an overview of different methods exemplified with cationic magnetoliposomes. Contrast Media Mol Imaging. 2009;4(5):207-219.

49. Tartaj P, del Puerto Morales M, Veintemillas-Verdaguer S, GonzálezCarreño T, Serna CJ. The preparation of magnetic nanoparticles for applications in biomedicine. J Phys D Appl Phys. 2003;36(13):R182.

50. Lam UT, Mammucari R, Suzuki K, Foster NR. Processing of iron oxide nanoparticles by supercritical fluids. Ind Eng Chem Res. 2008;47(3):599-614.

51. Kojima K, Miyazaki M, Mizukami F, Maeda K. Selective formation of spinel iron oxide in thin films by complexing agent-assisted sol-gel processing. J Sol-Gel Sci Technol. 1997;8(1-3):77-81.

52. Ennas G, Musinu A, Piccaluga G, et al. Characterization of iron oxide nanoparticles in an $\mathrm{Fe} 2 \mathrm{O} 3-\mathrm{SiO} 2$ composite prepared by a sol-gel method. Chem Mat. 1998;10(2):495-502.

53. Tadić M, Marković D, Spasojević V, et al. Synthesis and magnetic properties of concentrated $\alpha-\mathrm{Fe} 2 \mathrm{O} 3$ nanoparticles in a silica matrix. J Alloys Comp. 2007;441(1):291-296.

54. Hasany F, Abdurahman NH, Sunarti AR, Jose R. Magnetic iron oxide nanoparticles: chemical synthesis and applications review. Curr Nanosci. 2013;9(5):561-575.

55. Gonzalez-Carreno T, Morales MP, Gracia M, Serna CJ. Preparation of uniform $\gamma$-Fe $2 \mathrm{O} 3$ particles with nanometer size by spray pyrolysis. Mater Lett. 1993;18(3):151-155.

56. Dumitrache F, Morjan I, Alexandreseu R, et al. Iron-iron oxide core-shell nanoparticles synthesized by laser pyrolysis followed by superficial oxidation. Appl Surf Sci. 2005;247(1):25-31. 
57. Tartaj P, Morales MP, Gonzalez-Carreno T, et al. Advances in magnetic nanoparticles for biotechnology applications. J Magn Magn Mater. 2005;290:28-34.

58. Kumfer BM, Shinoda K, Jeyadevan B, Kennedy IM. Gas-phase flame synthesis and properties of magnetic iron oxide nanoparticles with reduced oxidation state. J Aerosol Sci. 2010;41(3):257-265.

59. Fievet F, Lagier JP, Blin B, Beaudoin B, Figlarz M. Homogeneous and heterogeneous nucleations in the polyol process for the preparation of micron and submicron size metal particles. Solid State Ionics. 1989;32:198-205.

60. Jezequel D, Guenot J, Jouini N, et al. Submicrometer zinc oxide particles: Elaboration in polyol medium and morphological characteristics. J Mater Res. 1995;10(01):77-83.

61. Joseyphus RJ, Shinoda K, Kodama D, Jeyadevan B. Size controlled Fe nanoparticles through polyol process and their magnetic properties Mater Chem Phys. 2010;123(2):487-493.

62. Hao Y, Teja AS. Continuous hydrothermal crystallization of $\alpha-\mathrm{Fe} 2$ O 3 and Co 3 O 4 nanoparticles. J Mater Res. 2003;18(02):415-422.

63. Xu C, Lee J, Teja AS. Continuous hydrothermal synthesis of lithium iron phosphate particles in subcritical and supercritical water. J Supercrit Fluids. 2008;44(1):92-97.

64. Hassanjani-Roshan A, Reza Vaezi M, Shokuhfar A, Rajabali Z. Synthesis of iron oxide nanoparticles via sonochemical method and their characterization. Particuology. 2011;9(1):95-99.

65. Ashokkumar M, Lee J, Kentish S, Grieser F. Bubbles in an acoustic field: an overview. Ultrason Sonochem. 2007;14(4):470-475.

66. Wang XK, Chen GH, Guo WL. Sonochemical degradation kinetics of methyl violet in aqueous solutions. Molecules. 2003;8(1):40-44.

67. Pinkas J, Reichlova V, Zboril R, Moravec Z, Bezdicka P, Matejkova J. Sonochemical synthesis of amorphous nanoscopic iron(III) oxide from $\mathrm{Fe}(\mathrm{acac}) 3$. Ultrason Sonochem. 2008;15(3):257-264.

68. Kijima N, Yoshinaga M, Awaka J, Akimoto J. Microwave synthesis, characterization, and electrochemical properties of $\alpha$-Fe 2 O 3 nanoparticles. Solid State Ionics. 2011;192(1):293-297.

69. Parsons J, Luna C, Botez CE, Elizalde J, Gardea-Torresdey JL. Microwave-assisted synthesis of iron (III) oxyhydroxides/oxides characterized using transmission electron microscopy, X-ray diffraction, and X-ray absorption spectroscopy. J Phys Chem Solids. 2009; 70(3):555-560.

70. Mahmoudi M, Simchi A, Imani M, Hafeli UO. Superparamagnetic iron oxide nanoparticles with rigid cross-linked polyethylene glycol fumarate coating for application in imaging and drug delivery. $J$ Phys Chem C. 2009;113(19):8124-8131.

71. Ittrich H, Peldschus K, Raabe N, Kaul M, Adam G. Superparamagnetic iron oxide nanoparticles in biomedicine: applications and developments in diagnostics and therapy. Rofo. 2013;185(12):1149-1166.

72. Estelrich J, Escribano E, Queralt J, Busquets MA. Iron oxide nanoparticles for magnetically-guided and magnetically-responsive drug delivery. Int J Mol Sci. 2015;16(4):8070-8101.

73. Xu P, Zeng GM, Huang DL, et al. Use of iron oxide nanomaterials in wastewater treatment: a review. Science of the Total Environment. 2012;424:1-10

74. Amendola V, Riello P, Meneghetti M. Magnetic nanoparticles of iron carbide, iron oxide, iron@ iron oxide, and metal iron synthesized by laser ablation in organic solvents. J Phys Chem C. 2010;115(12) 5140-5146.

75. Dadashi S, Poursalehi R, Delavari H. Structural and optical properties of pure iron and iron oxide nanoparticles prepared via pulsed Nd: YAG laser ablation in liquid. Procedia Mater Sci. 2015;11:722-726.

76. Lu Y, Yin Y, Mayers BT, Xia Y. Modifying the surface properties of superparamagnetic iron oxide nanoparticles through a sol-gel approach. Nano Lett. 2002;2(3):183-186.

77. Sun Y-P, Lia X-Q, Zhanga W-X, Wang HP. A method for the preparation of stable dispersion of zero-valent iron nanoparticles. Coll Surfaces A Physicochem Eng Aspects. 2007;308(1):60-66.

78. Xia T, Wang J, Wu C, et al. Novel complex-coprecipitation route to form high quality triethanolamine-coated $\mathrm{Fe} 3 \mathrm{O} 4$ nanocrystals: their high saturation magnetizations and excellent water treatment properties. CrystEngComm. 2012;14(18):5741-5744.
79. Jain TK, Reddy MK, Morales MA, Leslie-Pelecky DL, Labhasetwar V Biodistribution, clearance, and biocompatibility of iron oxide magnetic nanoparticles in rats. Mol Pharm. 2008;5(2):316-327.

80. Hui C, Shen C, Tian J, et al. Core-shell Fe 3 O 4@ SiO 2 nanoparticles synthesized with well-dispersed hydrophilic Fe $3 \mathrm{O} 4$ seeds. Nanoscale. 2011;3(2):701-705.

81. Petcharoen K, Sirivat A. Synthesis and characterization of magnetite nanoparticles via the chemical co-precipitation method. Mater Sci Eng B. 2012;177(5):421-427.

82. Dozier D, Palchoudhury S, Bao Y. Synthesis of iron oxide nanoparticles with biological coatings. J Sci Health Univ Alabama. 2010;7: 16-18.

83. Mahdavi M, Ahmad MB, Haron MJ, et al. Synthesis, surface modification and characterisation of biocompatible magnetic iron oxide nanoparticles for biomedical applications. Molecules. 2013;18(7): 7533-7548.

84. Hamley IW. Nanotechnology with soft materials. Angew Chem Int Ed Engl. 2003;42(15):1692-1712.

85. Tepper T, Ilievski F, Ross CA, et al. Magneto-optical properties of iron oxide films. J Appl Phys. 2003;93(10):6948-6950.

86. Ghosh S, Jiang W, McClements JD, Xing B. Colloidal stability of magnetic iron oxide nanoparticles: influence of natural organic matter and synthetic polyelectrolytes. Langmuir. 2011;27(13):8036-8043.

87. Kango S, Kalia S, Celli A, Njuguna J, Habibi Y, Kumar R. Surface modification of inorganic nanoparticles for development of organicinorganic nanocomposites - a review. Prog Polym Sci. 2013;38(8): 1232-1261.

88. Castelló J, Gallardo M, Busquets MA, Estelrich J. Chitosan (or alginate)-coated iron oxide nanoparticles: a comparative study. Coll Surfaces A Physicochem Eng Aspects. 2015;468:151-158.

89. Massia SP, Stark J, Letbetter DS. Surface-immobilized dextran limits cell adhesion and spreading. Biomaterials. 2000;21(22):2253-2261.

90. Ghosh Chaudhuri R, Paria S. Core/shell nanoparticles: classes, properties, synthesis mechanisms, characterization, and applications. Chem Rev. 2011;112(4):2373-2433.

91. Gupta AK, Curtis AS. Surface modified superparamagnetic nanoparticles for drug delivery: interaction studies with human fibroblasts in culture. J Mater Sci Mater Med. 2004;15(4):493-496.

92. Berry CC, Wells S, Charles S, Curtis AS. Dextran and albumin derivatised iron oxide nanoparticles: influence on fibroblasts in vitro. Biomaterials. 2003;24(25):4551-4557.

93. D’Souza AJM, Schowen RL, Topp EM. Polyvinylpyrrolidone-drug conjugate: synthesis and release mechanism. J Control Release. 2004;94(1):91-100.

94. Sahoo Y, Pizem H, Fried T, et al. Alkyl phosphonate/phosphate coating on magnetite nanoparticles: a comparison with fatty acids. Langmuir. 2001;17(25):7907-7911.

95. Shan GB, Xing JM, Luo MF, Liu HZ, Chen JY. Immobilization of Pseudomonas delafieldii with magnetic polyvinyl alcohol beads and its application in biodesulfurization. Biotechnol Lett. 2003;25(23): 1977-1981.

96. Burugapalli K, Koul V, Dinda AK. Effect of composition of interpenetrating polymer network hydrogels based on poly(acrylic acid) and gelatin on tissue response: a quantitative in vivo study. J Biomed Mater Res A. 2004;68(2):210-218.

97. Lewin M, Carlesso N, Tung CH, et al. Tat peptide-derivatized magnetic nanoparticles allow in vivo tracking and recovery of progenitor cells Nat Biotechnol. 2000;18(4):410-414.

98. Denizot B, Tanguy G, Hindre F, Rump E, Jacques Le Jeune J, Jallet P. Phosphorylcholine coating of iron oxide nanoparticles. J Colloid Interface Sci. 1999;209(1):66-71.

99. Soenen SJ, Himmelreich U, Nuytten N, De Cuyper M. Cytotoxic effects of iron oxide nanoparticles and implications for safety in cell labelling. Biomaterials. 2011;32(1):195-205.

100. Khor E, Lim LY. Implantable applications of chitin and chitosan. Biomaterials. 2003;24(13):2339-2349.

101. Olsen D, Yang C, Bodo M, et al. Recombinant collagen and gelatin for drug delivery. Adv Drug Deliv Rev. 2003;55(12):1547-1567. 
102. Hyeon T. Chemical synthesis of magnetic nanoparticles. Chem Commun. 2003(8):927-934.

103. Sarkar DJ, Singh A, Mandal P, Kumar A, Parmar BS. Synthesis and characterization of poly (CMC-g-cl-PAam/Zeolite) superabsorbent composites for controlled delivery of zinc micronutrient: swelling and release behavior. Polym Plast Technol Eng. 2015;54(4):357-367.

104. Sosa IO, Noguez C, Barrera RG. Optical properties of metal nanoparticles with arbitrary shapes. J Phys Chem B. 2003;107(26):6269-6275.

105. Mohapatra M, Anand S. Synthesis and applications of nanostructured iron oxides/hydroxides-a review. Int J Eng Sci Technol. 2010;2(8):127-146.

106. Hiemstra T, Rahnemaie R, van Riemsdijk WH. Surface complexation of carbonate on goethite: IR spectroscopy, structure and charge distribution. J Colloid Interface Sci. 2004;278(2):282-290.

107. Lee JH, Huh YM, Jun YW, et al. Artificially engineered magnetic nanoparticles for ultra-sensitive molecular imaging. Nat Med. 2007;13(1):95-99.

108. Rossi LM, Costa NJS, Silva FP, Wojcieszak R. Magnetic nanomaterials in catalysis: advanced catalysts for magnetic separation and beyond. Green Chem. 2014;16(6):2906-2933.

109. Chatterjee J, Haik Y, Chen C-J. Size dependent magnetic properties of iron oxide nanoparticles. J Magn Magn Mater. 2003;257(1):113-118.

110. Mahmoudi M, Simchi A, Imani M, et al. A new approach for the in vitro identification of the cytotoxicity of superparamagnetic iron oxide nanoparticles. Colloids and Surfaces B: Biointerfaces. 2010;75(1):300-309.

111. Mahmoudi M, Sant S, Wang B, Laurent S, Sen T. Superparamagnetic iron oxide nanoparticles (SPIONs): development, surface modification and applications in chemotherapy. Adv Drug Deliv Rev. 2011;63(1):24-46.

112. Gupta AK, Naregalkar RR, Vaidya VD, Gupta M. Recent advances on surface engineering of magnetic iron oxide nanoparticles and their biomedical applications. Nanomedicine (Lond). 2007;2(1):23-39.

113. Estelrich J, Sánchez-Martín MJ, Busquets MA. Nanoparticles in magnetic resonance imaging: from simple to dual contrast agents. Int J Nanomedicine. 2015;10:1727-1741.

114. Guo S, Sun S. FePt nanoparticles assembled on graphene as enhanced catalyst for oxygen reduction reaction. $\mathrm{J} \mathrm{Am} \mathrm{Chem} \mathrm{Soc.}$ 2012;134(5):2492-2495.

115. Lemire JA, Harrison JJ, Turner RJ. Antimicrobial activity of metals: mechanisms, molecular targets and applications. Nat Rev Microbiol. 2013;11(6):371-384

116. Srivastava N. Iron nanoparticles induced toxicity in Sesbania cannabina: a morphological aspect. Adv Sci Focus. 2014;2(2):135-139.

117. Nel AE, Mädler L, Velegol D, et al. Understanding biophysicochemical interactions at the nano-bio interface. Nat Mater. 2009;8(7):543-557.

118. Aslani F, Bagheri S, Muhd Julkapli N, Juraimi AS, Hashemi FS, Baghdadi A. Effects of engineered nanomaterials on plants growth: an overview. The Scientific World Journal. 2014;2014.

119. Servin A, Elmer W, Mukherjee A, et al. A review of the use of engineered nanomaterials to suppress plant disease and enhance crop yield. J Nanopart Res. 2015;17(2):1-21.

120. Zhang W-X. Nanoscale iron particles for environmental remediation: an overview. J Nanopart Res. 2003;5(3-4):323-332.

121. Bystrzejewska-Piotrowska G, Golimowski J, Urban PL. Nanoparticles: their potential toxicity, waste and environmental management. Waste Manag. 2009;29(9):2587-2595.

122. Zhang Y, Chen Y, Westerhoff P, Crittenden J. Impact of natural organic matter and divalent cations on the stability of aqueous nanoparticles. Water Res. 2009;43(17):4249-4257.

123. Wang D, Kou R, Choi D, et al. Ternary self-assembly of ordered metal oxide - graphene nanocomposites for electrochemical energy storage. ACS Nano. 2010;4(3):1587-1595.

124. Matsui I. Nanoparticles for electronic device applications: a brief review. J Chem Eng Japan. 2005;38(8):535-546.
125. Pisanic TR 2nd, Blackwell JD, Shubayev VI, Fiñones RR, Jin S. Nanotoxicity of iron oxide nanoparticle internalization in growing neurons. Biomaterials. 2007;28(16):2572-2581.

126. Zhu X, Zhu Y, Murali S, Stoller MD, Ruoff RS. Nanostructured reduced graphene oxide/ $\mathrm{Fe} 2 \mathrm{O} 3$ composite as a high-performance anode material for lithium ion batteries. ACS Nano. 2011;5(4):3333-3338.

127. Foley RW, Wiek A. Scenarios of nanotechnology innovation vis-à-vis sustainability challenges. Futures. 2014;64:1-14.

128. Smith D, Edwards JL, Edwards JL, Inventors. Concrete Admixture Device and Method of Using Same. US Patent 4,961790. 9 October 1990.

129. Gojova A, Lee JT, Jung HS, Guo B, Barakat AI, Kennedy IM. Effect of cerium oxide nanoparticles on inflammation in vascular endothelial cells. Inhal Toxicol. 2009;21(sup1):123-130.

130. Mayer AC, Ulrich A, Czerwinski J, Mooney JJ. Metal-Oxide Particles in Combustion Engine Exhaust. SAE Technical Paper; 2010.

131. Ding B, Wang M, Yu J, Sun G. Gas sensors based on electrospun nanofibers. Sensors. 2009;9(3):1609-1624.

132. Xiao S, Shen M, Guo R, Wang S, Shi X. Immobilization of zerovalent iron nanoparticles into electrospun polymer nanofibers: synthesis, characterization, and potential environmental applications. J Phys Chem C. 2009;113(42):18062-18068.

133. Choi HC, Kundaria S, Wang D, et al. Efficient formation of iron nanoparticle catalysts on silicon oxide by hydroxylamine for carbon nanotube synthesis and electronics. Nano Lett. 2003;3(2):157-161.

134. Lin C-R, Chiang R-K, Wang J-S, Sung T-W. Magnetic properties of monodisperse iron oxide nanoparticles. J Appl Phys. 2006;99(8):08N710.

135. Chouly C, Pouliquen D, Lucet I, Jeune JJ, Jallet P. Development of superparamagnetic nanoparticles for MRI: effect of particle size, charge and surface nature on biodistribution. J Microencapsul. 1996;13(3):245-255.

136. Owens DE 3rd, Peppas NA. Opsonization, biodistribution, and pharmacokinetics of polymeric nanoparticles. Int J Pharm. 2006; 307(1):93-102.

137. Edge D, Shortt CM, Gobbo OL, et al. Pharmacokinetics and biodistribution of novel super paramagnetic iron oxide nanoparticles (SPIONs) in the anaesthetized pig. Clinical and Experimental Pharmacology and Physiology. 2016;43(3):319-326.

138. Shanehsazzadeh S, Oghabian MA, Daha FJ, Amanlou M, Allen BJ. Biodistribution of ultra small superparamagnetic iron oxide nanoparticles in BALB mice. J Radioanal Nucl Chem. 2013;295(2):1517-1523.

139. Oghabian MA, Farahbakhsh NM. Potential use of nanoparticle based contrast agents in MRI: a molecular imaging perspective. $J$ Biomed Nanotechnol. 2010;6(3):203-213.

140. Hanini A, Schmitt A, Kacem K, Chau F, Ammar S, Gavard J. Evaluation of iron oxide nanoparticle biocompatibility. Int J Nanomedicine. 2011;6:787-794.

141. Mejías R, Pérez-Yagüe S, Roca AG, et al. Liver and brain imaging through dimercaptosuccinic acid-coated iron oxide nanoparticles. Nanomedicine. 2010;5(3):397-408.

142. Brigger I, Dubernet C, Couvreur P. Nanoparticles in cancer therapy and diagnosis. Adv Drug Deliv Rev. 2012;64:24-36.

143. Chaves S, Silva LP, Lacava ZGM, Morais PC, Azevedo RB. Interleukin-1 and interleukin- 6 production in mice's lungs induced by 2 , 3 meso-dimercaptosuccinic-coated magnetic nanoparticles. J Appl Phys. 2005;97(10):10Q915.

144. Ruiz A, Hernández Y, Cabal C, et al. Biodistribution and pharmacokinetics of uniform magnetite nanoparticles chemically modified with polyethylene glycol. Nanoscale. 2013;5(23):11400-11408.

145. Nissim J, Robson J. Preparation and standardisation of saccharated iron oxide for intravenous administration. Lancet. 1949; 253(6556):686-689.

146. Richter GW. The cellular transformation of injected colloidal iron complexes into ferritin and hemosiderin in experimental animals a study with the aid of electron microscopy. J Exp Med. 1959;109(2):197-216. 
147. Roco MC, MC Hersam, Mirkin CA. Innovative and responsible governance of nanotechnology for societal development. Nanotechnology Research Directions for Societal Needs in 2020. Springer; 2011:561-617.

148. Buzea C, Pacheco II, Robbie K. Nanomaterials and nanoparticles: sources and toxicity. Biointerphases. 2007;2(4):MR17-MR71.

149. Silva J, Fernandes AR, Baptista PV. Application of Nanotechnology in Drug Delivery. 2014.
150. Handy RD, Shaw BJ. Toxic effects of nanoparticles and nanomaterials: implications for public health, risk assessment and the public perception of nanotechnology. Health Risk Soc. 2007;9(2):125-144.

151. Ryan P, Delhaize E, Jones D. Function and mechanism of organic anion exudation from plant roots. Ann Rev Plant Biol. 2001;52(1):527-560.

152. Dinesh R, Anandaraj M, Srinivasan V, Hamza S. Engineered nanoparticles in the soil and their potential implications to microbial activity Geoderma. 2012;173:19-27.

\section{Publish your work in this journal}

Nanotechnology, Science and Applications is an international, peer-reviewed, open access journal that focuses on the science of nanotechnology in a wide range of industrial and academic applications. It is characterized by the rapid reporting across all sectors, including engineering, optics, bio-medicine, cosmetics, textiles, resource sustainability and science. Applied research into nano-materials,

\section{Dovepress}

particles, nano-structures and fabrication, diagnostics and analytics, drug delivery and toxicology constitute the primary direction of the journal. The manuscript management system is completely online and includes a very quick and fair peer-review system, which is all easy to use. Visit http://www.dovepress.com/ testimonials.php to read real quotes from published authors.

Submit your manuscript here: https://www.dovepress.com/nanotechnology-science-and-applications-journa/ 